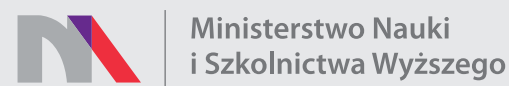

Digitalizacja archiwalnych numerów czasopisma naukowego Analecta Cracoviensia 1-24 (1969-1992) i ich publikacja w otwartym dostępie - zadanie finansowane w ramach umowy 672/P-DUN/2017 ze środków Ministra Nauki i Szkolnictwa Wyższego przeznaczonych na działalność upowszechniającą naukę

\title{
SAKRAMENTALNA STRUKTURA KOŚCIOŁA W SCHEMATACH KOMISJI PRZYGOTOWAWCZYCH II SOBORU WATYKAŃSKIEGO
}

Wkrótce po ukonstytuowaniu się przygotowawczych organów Vaticanum II Sekretarz generalny Komisji centralnej przekazał dn. 9. 7. 1960 r., z polecenia Papieża Jana XXIII, Komisjom i Sekretariatom powołanym do opracowania problematyki obrad soborowych zestaw kwestii, jakimi powinny się zająć ${ }^{1}$. Jeżeli idzie o Komisję teologiczną, to ta, między innymi, otrzymała następujące plecenie: „Kościół katolicki. Konstytucja I Soboru Watykańskiego o Kościele katolickim powinna zostać uzupełniona i udoskonalona, głównie co do: a) Ciała mistycznego Chrystusa; b) Episkopatu; c) Laikatu (świeckich) 2". Oczywiście nie oznacza to, że inne Komisje przygotowawcze miały w ogóle zrezygnować z problematyki eklezjologicznej. Niemniej, miały ją uwzględniać tylko o tyle, o ile dyktowały to zadania, postawione im do realizacji ${ }^{3}$.

W niniejszym studium podejmujemy próbę przestudiowania i przedstawienia problemu Kościoła w okresie bezpośrednich przygotowań Vaticanum II, tzn. w latach 1960-1962. Będzie nam przy tym chodziło nie o całość eklezjologii katolickiej, lecz tylko o pewien jej aspekt, a mianowicie, będziemy usiłowali dać odpowiedź na pytanie, czy i o ile doszła wtedy do głosu idea sakramentalności eklezjalnej: Kościoła pojętego jako powszechny sakrament zbawienia. Uczynimy to głównie w oparciu o tzw. Schematy soborowe, tzn. projekty dokumentów, przygotowane przez wspomniane wyżej Komisje i Sekretariaty do dyskusji i ewentualnego uchwalenia przez Sobór.

1 Acta et Documenta Concilio oecumenico Vaticano II apparando. Series II (Praeparatoria) $=($ SP) , vol. II: Acta Pontificiae Commissionis centralis praeparatoriae Concilii oecumenici Vaticani II, Pars I: Sessio prima: 12-20 iunii 1961. Sessio secunda: 7-17 novembris 1961 (sub secreto), TPV 1965, 407-415 (Quaestiones Commissionibus Praeparatoriis Concilii Oecumenici Vaticani II positae).

2 Tamże, 408: „Commissio theologica. 2. De Ecclesia Catholica. Constitutio de Ecclesia Catholica, a Concilio Vaticano I edita, compleatur et perficiatur, praesertim quoad: a) Corpus Christi mysticum; b) Episcopatum; e) Laicatum".

3 Tak np. władzą biskupów miała się jeszcze zająć Komisja biskupów i zarządzania diecezją, a świeckimi Komisja apostolstwa świeckich. Tamże, 409, 414. 


\section{SCHEMATY SOBOROWYCH KOMISJI PRZYGOTOWAWCZYCH}

Jak wiadomo, akcja sondażowa zbierania materiałów przez Komisję przedprzygotowawczą II Soboru Watykańskiego była przewidziana na okres niespełna jednego roku. Z chwila jej zakończenia Komisja przestała istnieć. W jej miejsce papież Jan XXIII powołał Motu proprio Superno Dei nutu (5. 6. 1960) dziesięć Komisji przygotowawczych i dwa Sekretariaty. Zasadniczym celem tych organów było przestudiowanie tematów wskazanych przez papieża na Sobór z uwzględnieniem życzeń (votis) biskupów oraz uwag i propozycji (monitis et propositis) dykasterii Kurii Rzymskiej. Studium to miało zakończyć się przygotowaniem tzw. Schematów (Schemata), czyli projektów ewentualnych dokumentów soborowych. Nieco inne zadanie zostało postawione przygotowawczej Komisji centralnej. Polegało ono głównie na koordynacji prac poszczególnych Komisji oraz, po gruntownym przemyśleniu, na referowaniu ich wyników papieżowi celem ustalenia przezeń problematyki obrad soborowych. Do Komisji tej należało także opracowanie regulaminu Soboru. Pracom jej przewodniczył sam papież, ewentualnie delegowany przez papieża kardynał. Sekretarz Komisji centralnej nazywał się sekretarzem generalnym. Został nim P. Felici, audytor Roty rzymskiej. Działalność wszystkich Komisji i Sekretariatów przygotowawczych trwała dwa lata $(1960-1962)^{4}$.

Rezultaty tej działalności zostały $z$ polecenia papieża opublikowane drukiem w latach 1964-1969 przez Sekretariat generalny Vaticanum II w drugiej Serii, zwanej przygotowawczą jako Akta i Dokumenty stadium

4 Litterae apostolicae motu proprio datae Commissiones Concilio Vaticano secundo apparando instituuntur, w: Acta et Documenta Concilio Oecumenico Vaticano II apparando. Series I (Antepraeparatoria) $=(S A)$, vol. I: Acta Summi Pontificis Joannis XXIII, TPV 1960, 93-96. Tekst włoski tamże, 96-99. Dokument ten między innymi postanawiał: „1. Ad apparandum Concilium Oecumenicum Vaticanum alterum instituuntur Commissiones, quae Praeparatoriae appellantur, in idque tendunt ut res seu materias per Nos selectas studio et pervestigationi subiciant, rite perspectis sacrorum Antistitum votis atque Dicasteriorum Curiae Romanae monitis et propositis. ... 7. Commissiones praeparatoriae constituuntur decem: ... Commissiones igitur sunt, quae sequuntur: a) Commissio theologica, cuius erit quaestiones ad Scripturam Sanctam, Sacram Traditionem, fidem moresque spectantes perpendere et perverstigare; b) Commissio de Episcopis et de dioeceseon regimine; c) Commissio de disciplina cleri et populi christiani; d) Commissio de Religiosis; e) Commissio de disciplina Sacramentorum; f) Commissio de Sacra Liturgia; g) Commissio de Studiis et Seminariis; h) Commissio de Ecclesiis orientalibus; i) Commissio de Missionibus; 1) Commissio de apostolatu laicorum in omnibus quae ad actionem catholicam, religiosam atque socialem, spectant. ... 10. Instituitur demum Commissio Centralis, cui Nos praeerimus sive per Nosmet Ipsos sive per S.R.E. Cardinalem a Nobis designandum. ... 14. Commissionis Centralis munus esto sequi ac. si necesse sit, in ordinem disponere singularum Commissionum labores, atque illarum conclusiones, rite perpensas, ad Nos deferre, ut res in Concilio Oecumenico tractandas Nosmetipsi statuamus. Commissioni Centrali munus quoque committitur proponendi normas, quae ad or dinem in Concilio servandum pertineant". Punkty 8 i 9 ustanawiały Sekretariaty dla środków społecznego przekazu i jedności chrześcijan. Tamże, 94-96. Por. AAS, 52 (1960), 433-437; L'Osservatore Romano, 5 giugno 1960. 
przygotowawczego II Soboru Watykańskiego (Acta et Documenta Concilio oecumenico Vaticano II apparando. Series II. [Praeparatoria]). Dokumentacja ta dzieli się na trzy woluminy i zawiera: Akta papieża Jana XXIII za lata 1960-1962 (volumen I), Akta papieskiej Komisji centralnej przygotowawczej (volumen II), Akta Komisji i Sekretariatów przygotowawczych (volumen III). Podobnie jak w Serii przedprzygotowawczej na wszystkich woluminach i ich poszczególnych tomach (pars), za wyjątkiem woluminu pierwszego, figuruje klauzula sub secreto.

Należy jednakże zauważyć, że Seria przygotowawcza niejednakowo relacjonuje o pracach przedsoborowych Komisji i Sekretariatów. W całości odtwarza ona tylko obrady Komisji centralnej. Wolumen II, obejmujący cztery tomy, rejestruje jej dyskusję i głosowanie według oddanego na piśmie i podpisanego głosu. Jeśli głos nie został złożony na piśmie, odtworzono go $z$ taśmy magnetofonowej. Dla ułatwienia studium tego materiału, wolumen II publikuje ponadto teksty dyskutowanych Schematów, składane Relacje oraz inne dane, np. wygłoszone wtedy przemówienia papieskie czy protokoły z posiedzeń (Processus verbales Congregationum). Ponieważ skład personalny Komisji centralnej miał charakter bardzo reprezentatywny ${ }^{5}$ - obejmował w obrębie ok. 150 osób w pierwszym rzędzie przewodniczących innych Komisji oraz Sekretariatów przygotowawczych - dlatego obrady jej informują również o ważniejszych problemach, z jakimi się poszczególne Komisje borykały, przygotowując swoje dokumenty. Szczególnie cenne pod tym względem są wspomniane już Relacje. Zawierają bowiem sporo oficjalnych wiadomości na temat prac związanych z genezą Schematów, np. odnośnie sposobu ich przygotowania, nazwisk autorów, odbytych konsultacji ${ }^{6}$. W rezultacie, materiał utrwalający posiedzenia Komisji centralnej pokazuje ją do pewnego stopnia jako małą aulę soborową, ponieważ wszystkie ważniejsze problemy tam podniesione, zjawiły się również podczas obrad Vaticanum II i to łącznie $\mathrm{z}$ różnicami, jakie zachodziły $\mathrm{w}$ podejściu do

5 Zob. Sodales et Consiliarii Commissionis centralis. SP, vol. II, pars I, 9-18. Z Polaków członkiem Komisji centralnej był tylko arcybiskup metropolita gnieźnieńsko-warszawski, Kard. Stefan Wyszyński, Prymas Polski. Wzią on udział w posiedzeniach plenarnych tylko czwartej sesji odbytej od 19 do 27 lutego 1962 r. zob. $S P$, vol. II, pars II.

${ }_{6}$ Por. np. Relationes Praesidum Commissionum praeparatorium za pierwszy rok ich działalności na pierwszym posiedzeniu plenarnym centralnej Komisji przygotowawczej (12. 6. 1961) podczas pierwszej jej sesji. SP, vol. II, pars I, 131-168. W związku z pracami Komisji teologicznej nad Schematem o Kościele dowiadujemy się tam między innymi: „Prima sub-commissio, cuius est agere 〈de Ecclesia〉, hactenus 17 sessiones habuit, plures frequentioresque habitura usque ad mensem iulium: nam diversitas opinionum et quaestionum gravitas opus expeditu difficillimum fecerunt. Emitatur autem ut quam primum integrum schema Constitutionis suae perficiat, ubi res erit de quaestionibus agitatis, utputa de vera indole missionis Ecclesiae, de Sacramento episcopatus, de habitudine Episcoporum ad Summum Pontificem, de gradu laicorum in Ecclesia, de Oecumenismo, de rationibus inter Ecclesiam et Statum". Tamże, 131. 
bardziej kontrowersyjnych zagadnien, co dotyczyło tu głównie Kómisji teologicznej i Sekretariatu dla jedności chrześcijan ${ }^{7}$. U niektórych mówców istnieje nawet tożsamość treściowa przemówień wygłoszonych podczas obrad Komisji centralnej i na auli soborowej ${ }^{8}$.

Jeżeli idzie o prace pozostałych Komisji i Sekretariatów przygotowujących problematykę merytoryczną II Soboru Watykańskiego, to nie zostały one w Serii przygotowawczej w podobny sposób odtworzone i utrwalone. Wolumen III zbiera jedynie w dwóch tomach pierwsze rezultaty ich prac, tzn. projekty Schematów. Należy jednak zauważyć, że nie był to ostateczny owoc prac przygotowawczych. Po dyskusji na Komisji centralnej poszczególne teksty $\mathrm{w}$ porozumieniu z zainteresowanymi Komisjami i Sekretariatami były jeszcze raz opracowywane przez Podkomisję Komisji centralnej, specjalnie w tym celu powołaną. Wprowadzone do nich wówczas korekty miały dość zróżnicowany charakter. Niekiedy były minimalne lub prawie żadne, w innych znowu przypadkach dość istotne. W każdym razie ta wersja Schematów, która wchodziła pod obrady Soboru, była już drugą z kolei i ją właśnie należy uważać za ostateczny wynik soborowych przygotowań ${ }^{9}$.

; Bardzo widoczny przykład rozbieżności pomiędzy Komisją teologiczną i Sekretariatem dla jedności chrześcijan stanowi dyskusja podczas VII Sesji Komisji centralnej, odbyta 19 i 20. 6. 1962 nad dziewiątym rozdziałem ,De relationibus inter Ecclesiam et Statum necnon de tolerantia religiosa" Schematu De Ecclesia, przygotowanego przez Komisję teologiczną i Schematem De libertate religiosa zaproponowanym przez Sekretariat dla jedności chrześcijan. Zob. SP, vol. II, pars IV: Sessio septima: 12-19 Iunii 1962, TPV 1968, 657-746. Atmosfera dyskusji była tak napięta, że patriarcha Cheikho złożył następujące oświadczenie przy głosowaniu: ,Enixe et reverenter rogo omnes Em. mos et Exc. mos Patres ut utrumque schema (nempe schema IX de Ecclesia et schema de libertate religiosa) non referatur ad Concilium, et hoc pro bono Ecclesiae et fidelium. Sufficiunt ea quae Summi Pontifices tradunt de hac re in singulis temporibus, in suis Encyclicis. Dominus Noster et Salvator totius mundi multa volebat dicere discipulis suis, sed non dixit, quia neque Apostoli, neque alii auditores poterant intelligere". Tamże, 738-739. - O centralnej Komisji przygotowawczej H. Schmidt napisal: „Nach den Worten Kardinal Alfrinks war diese Zentralkommission nicht nur eine internationale Versammlung, sie war die Kirche im kleinen und, wenn man will, ein Konzil im Kleinformat: In ihr war die "Stimme der gesamten Kirche zu hören". Die Konstutition über die heilige Liturgie. Vorgeschichte-Kommentar, Herder-Bücherei 1965, 74.

Por. przykładowo przemówienia Kard. A. Liénart, wygłoszone pod adresem Konstytucji De Ecclesia, w czasie posiedzenia Komisji centralnej (SP, vol. II, pars III, 997-998) i na auli soborowej, podczas pierwszej sesji Vaticanum II (AS, vol. I, pars IV: Congregationes generales XXXI-XXXVI, TPV 1971, 126-127).

" Szczegółową Relację na temat prac Komisji centralnej jako takiej i jej Podkomisji do rewizji Schematów złożył Kard. C. Confalonieri w związku z zarzutami, jakie postawiono pod adresem wprowadzonych modyfikacji do Schematu De Sacra Liturgia: „In postremis generalibus congregationibus mensis octobris nuper elapsi hic habitis bona utique fide dicta sunt, quae possunt confusionem ingerere circa apparata et emendata schemata Concilio postea subiicienda...

1) Munus commissionis centralis praeparatoriae definitum fuit a Summo Pontifice, n. 14 Motu Proprio Superno Dei nutu die 5 iunii 1960, scilicet: 〈Sequi ac, si necesse sit, in ordinem disponere singularum commissionum labores atque illarum conclusiones rite perpensas ad Nos deferre, ut res in Concilio Oecumenico tractandas Nosmetipsi statuamus $\rangle$. (Sunt verba Summi Pontificis). Quod munus confirmatum fuit in Normis ab ipso Summo Pontifice approbatis die 16 septembris 1961 et sodalibus distributis. 
Niemniej, publikacja woluminu III jest bardzo cenna. Zebranie w jedną całość rozrzuconego w różnych miejscach materiału bardzo ułatwia studium. Ma to tym większe znaczenie, że niektóre Schematy, nie będąc dyskutowane przez Komisję centralną w ogóle nie były drukowane. Tak więc dzięki woluminowi III istnieje kompletny ich zestaw. W sumie siedemdziesiąt sześć Schematów ${ }^{10}$.

2) Suffragio ergo Patrum commissionis centralis, dato per verba placet, non placet, placet iuxta modum, hoc tantum respiciebat: convenientiam praesentandi schemata Summo Pontifici. Suggestiones, emendationes, animadversiones a Patribus in disceptatione factae, ut singulae et qua tales, suffragationi subiectae non fuerunt nec erant subiiciendae, quia talis singulorum propositionum suffragatio a munere exsulabat. De cetero notum est quod multi Patres sententiam suam saepe exprimebant per verba generalia: Adhaereo his quae dixit Pater A et Pater B et Pater C, et ceteris, sed Patres A, B, C, et ceteri vota inter se disfformia et discordantia aliquando proposuerunt. Quaenam ergo adhaerentiam sententia?

3) Die 7 novembris 1961 vero, subcommissioni de schematibus emendandis tunc institutae, per decretum in publica sessione perlectum coram Summo Pontifice praeceptum fuit: 〈Ista subcommissio providebit emendandis schematibus, perpensis scilicet a sodalibus huius commissionis centralis propositis emendationibus $\rangle$.

4) Hoc sibi commissum munus subcommissio, iuxta constitutum iter, studuit rite adimplere. Omnes observationes commissionis centralis, systematicae collectae, transmissae sunt ad cardinalem praesidem commissionis originis ut eas, consultis tribus ipsius commissionis originis selectis membris, perpenderet et inde subcommissioni de schematibus emendandis significaret quaenam essent accipiendae aut reiciendae, argumentis adductis.

5) Tunc Patres cardinales subcommissionis, qui initio quinque, postea septem fuere, examinaverunt sive observationes sodalium commissionis centralis sive responsiones datas a commissione originis; ubi erant concordia, textus emandatus fuit sine ambage; ubi vero discordia, subcommissio, perpensis hic inde argumentis, pro munere sibi a Summo Pontifice commisso prudenter et scienter illas propositiones relegit, quas aptiores iudicavit.

6) Ad haec omnia perficienda, perplures conventus habuit subcommissio et assiduos labores per integrum annum produxit. Schemata autem variis voluminibus continentur, quorum primum illud est quod, iussu Summi Pontificis, transmissum fuit ad omnes conciliares Patres et nunc ipsi prae manibus habent. Discussio igitur Concilii et eius liberum et supremum iudicium non est de praeteritis, sed de schematibus prouti iacent in subiecto volumine". AS, vol. I, pars II: Congregationes generales X-XVIII, TPV 1970, 106-107. - Powstanie i skład Podkomisji do rewizji Schematów, zob. SP, vol. II, pars I, 434-435. - Tutaj należy jeszcze dodać, że W poprawionej wersji przez wzmiankowaną Podkomisję, tylko niewielka ilość Schematów ukazała się drukiem po zatwierdzeniu papieskim, bądź $w$ formie specjalnych fascykułów, bądź też ostatnio w Acta Synodalia. Jeżeli któreś z nich będą przedmiotem naszego zainteresowania, to rzecz zrozumiała, postaramy się je uwzględnić w granicach wymaganych przez charakter i zakres niniejszego studium.

10 Zob. SP, vol. III: Acta Commissionum et Secretariatuum praeparatoriorum Concilii Oecumenici Vaticani II, pars I, TPV 1969; pars II, TPV 1969 . I tak W pars I znajduja się Schematy: Commissio theologica (I. Formula nova professionis fidei; II. De fontibus revelationis; III. De ordine morali; IV. De deposito fidei pure custodiendo; V. De castitate, virginitate, matrimonio, familia; VI. De Ecclesia; VII. De beata Maria virgine matre Dei et matre hominum. Appendix: I. De communitate gentium; II. De ordine sociali); Commissio de e piscopis et de dioeceseon regimine (I. De dioeceseon partitione; II. De episcoporum coetu seu conferentia; III. De rationibus inter episcopos et SS. Curiae Romanae Congregationes; IV. De ratione inter episcopos et parochos; V. De episcoporum coadiutoribus et auxiliaribus deque episcoporum cessatione a munere pastorali; VI. Praecipuae de animarum cura quaestiones; VII. De rationibus inter episcopos et religiosos praesertim quoad apostolatus opera exercenda); Co m m issio de disciplina cleri et populi christiani (I. De distributione cleri; II. De clericorum vitae sanctitate; III. De habitu et tonsura clericali; IV. De 
Nie jest naszym zamiarem dawać tutaj jakąś, choćby nawet bardzo pobieżną ocenę Schematów zebranych w III woluminie Serii przygotowawczej. W dużej mierze uczynili to już dawno członkowie centralnej Komisji. Te, które weszły na porządek obrad soborowych, jeszcze raz spotkały się tam z całą gamą ocen, niekiedy nawet wzajemnie się wykluczających ${ }^{11}$. Jednakże równoczesna lektura całości tego materiału uprawnia do wypowiedzenia kilku uwag pod ich adresem. Przede wszystkim

paroeciarum provisione, unione, divisione; V. De obligationibus parochorum; VI. De officiis et beneficiis ecclesiasticis deque bonorum ecclesiasticorum administratione; VII. De patrimonio historico et artistico ecclesiastico; VIII. De parochorum obligationibus quod curam animarum; IX. De praeceptis ecclesiasticis; X. De catechetica populi christiani institutione; XI. De cura animarum et communismo; XII. De praevia librorum censura eorumque prohibitione; XIII. De censuris earumque reservatione; XIV. De modo procedendi in poenis in via administrativa infligendii; XV. De fidelium associationibus; XVI. De missarum stopendiis, de missarum onerum reductione, de piis ultimis voluntatibus; XVII. De promovendis ad ordines sacras is qui fuerunt pastores seu ministri acatholici); $\mathrm{Commissio}$ de religiosis (De statibus perfectionis adquirendae); Commissio de disciplina sacramentorum (I. De sacramento confirmationis; II. De sacramento poenitentiae; III. De sacramento ordinis; IV. De impedimentis ad matrimonium; V. De matrimoniis mixtis; VI. De consensu matriniali; VII. De forma celebrationis matrimonii; VIII. De processu matrimoniali; IX. De praeparatione ad matrimonium; $\mathrm{X}$. De sacerdotibus lapsis), a $\mathrm{w}$ pars II Schematy: Commissio de sacra liturgia (De sacra liturgia); Commissio de studiis et seminaris (I. De vocationibus ecclesiasticis fovendis; II. De sacrorum alumnis formandis; III. De studiis academicis ab universitatibus tum catholicis tum ecclesiasticis provehendis; IV. De scholis catholicis; V. De obsequio erga Ecclesiae Magisterium in tradendis disciplinis sacris. Appendix: De lingua latina in studiis ecclesiasticis rite excolenda); Commissio de Ecclesiis orientalibus (I. De ritibus in Ecclesia; II. De patriarchis orientalibus; III. De communicatione in sacris cum christianis orientalibus non catholicis; IV. De usu linguarum vernacularum in liturgiis; V. De Ecclesiae sacramentis; VI. De Ecclesiae praeceptis; VII. De facultatibus episcoporum; VIII. De cathechismo et catechetica institutione; IX. De Kalendario perpetuo et celebratione paschalis; $\mathrm{X}$. De officio divino Ecclesiarum orientalium; XI. De Ecclesiae unitate 〈ut unum sint〉); $\mathrm{Commissio} d \mathrm{e}$ missionibus (I. De regimine missionum; II. De disciplina cleri; III. De religiosis; IV. De sacramentis ac de sacra liturgia; V. De disciplina populi christiani; VI. De studiis clericorum; VII. De cooperatione missionali); Commissio de a postolatulaicorum (De apostolatu laicorum); Secretariatus de scriptis prelo edendis et de spectaculis, moderandis (De instrumentis diffusionis seu communicationis socialis); Secretariatus ad christianorum unitatem fovendam (I. De libertate religiosa; II. Necessitas orationis pro unitate christianorum maxime temporibus nostris; III. De oecumenismo catholico; IV. De verbo Dei. Appendix: De Iudacis). - Niedyskutowanymi przez Komisję centralną były tylko teksty zamieszczone w apendyksach, a więc: De communitate gentium; De ordine sociali; De lingua latina in studiis ecclesiasticis rite excolenda; De Iudacis. Prawie wszystkie Komisje, za wyjątkiem Komisji teologicznej, o zakonnikach, misji oraz obu Sekretariatów (środków społecznego przekazu i jedności chrześcijan) informowały także, kiedy i jak (,unanimi suffragio" czy tylko „maioritate suffragiorum") odnośny Schemat został przez nie zatwierdzony. Wiele z nich podało naewet dokładnie, ile głosów było ,za”, a ile ,przeciw” głosowanemu Schematowi. Tamże.

11 Jako pierwszy, glośny przypadek tego typu należy wymienić Schemat Komisji Teologicznej De fontibus revelationis. Wobec rozbieżności ocen tego Schematu Prezydium Soboru podczas XXIII (20. 11. 1962) posiedzenia plenarnego poddało pod głosowanie wniosek, czy należy przerwać debatę soborową, czy też dalej ją kontynuować. Na 2209 głosujących 1368 było ,tak" (placet), 822 ,nie" (non placet) i 19 głosów nieważnych (vota nulla). AS, vol. I, pars III: Congregationes generales XIX-XXX, TPV 1971, 220-222; 254-255. 
uderza duże zróżnicowanie treściowe omawianych Schematów. Jako ilustracja może służyć w tym względzie np. zestawienie obok siebie Schematów De deposito fidei pure custodiendo i De habitu et tonsura clericali, opracowanych odpowiednio przez Komisję teologiczną i Komisję dyscypliny (karności) kleru i ludu chrześcijańskiego ${ }^{12}$. Głębokie różnice widać także w sposobie opracowania podjętych problemów ${ }^{13}$. Wreszcie fakt istnienia wielu organów przygotowawczych musiał pociągnąc za sobą równoległe podejmowanie tych samych lub zbliżonych do siebie tematów ${ }^{14}$.

W naszym przypadku wszakże nie to wszystko jest najważniejsze. Pozostaje bowiem faktem, że Komisje i Sekretariaty przygotowawcze, niøzależnie od tego, jakie miałoby się zdanie odnośnie ich składu personalnego, stanowiły oficjalną reprezentację Kościoła, że praca, jaką włożyły w przygotowanie Schematów była olbrzymia, o czym między innymi świadczy wymownie ilość odbytych posiedzeń, i wreszcie, że wypracowane teksty były pomyślane jako projekty przyszłych dokumentów soborowych, a więc w zamierzeniu papieża i swych twórców miały się stać po dyskusji soborowej i wprowadzonych zmianach - wyrazem uroczystego nauczania Magisterium. I choć wiele $\mathrm{z}$ nich nie weszło w ogóle pod obrady Soboru, a te, które były dyskutowane, ulegały z reguły gruntownej przeróbce ${ }^{15}$ lub nawet bywały odrzucane ${ }^{16}$, to przecież pozosta-

12 Zob. SP, vol. III, pars I, 54-89; 362-363.

13 Aby się o tym przekonać, wystarczy np. porównać ze sobą Schemat De sacra liturgia (SP, vol. III, pars II, 9-68) ze Schematem De statibus perfectionis adquirendae (SP, vol. III, pars I, 433-495).

14. Odnosi się to w szczególności do: Commissio de episcopis et de dioeceseon regimine (SP, vol. III, pars I, 277-351); Commissio de disciplina cleri et populi christiani (tamże, 353-430), Commissio de Ecclesiis orientalibus (SP, vol. III, pars II, 187-238); Commissio de missionibus (tamże, 239-299). Oczywiście mamy tutaj do czynienia tylko z częściowym powtarzaniem się tej samej problematyki. Wymownym przykladem takiego powtarzania się są np. Schematy: De praeceptis ecclesiasticis Komisji dyscypliny kleru i ludu chrzéscijańskiego (SP, vol. III, pars I, 386-391) i De Ecclesiae praeceptis Komisji Kościołów wschodnich (SP, vol. III, pars II, $207-213)$

15 Tak np. Schemat o środkach spolecznego przekazu Ojcowie zaaprobowali tylko co do istoty. Poddana pod głosowanie propozycja brzmiała: ,Schema quoad substantiam placet. Et quidem maxime convenit, ut Ecclesia in magisterio conciliari de re tanti momenti pastoralis expresse pertractat. Perpensis observationibus a Patribus Conciliaribus factis extrahantur e schemate essentialia principia doctrinalia neanon generaliora lineamenta pastoralia per competentem commissionem conciliarem eo fine, ut - servata rei integritate - in breviorem formam redigantur et suo tempore suffragio Patrum subiiciantur'. AS, vol. I, pars III, 613 (Propositio circa schema de instrumentis communicationis socialis). Wynik głosowania zob. tamże, 635 .

16 Por. przypis 7. Wobec większości głosów postulujących przerwanie debaty nad Schematem De fontibus revelationis, mimo że nie stanowiła ona potrzebnych w takim przypadku dwóch trzecich, Papież Jan XXIII opowiedział się za nią, i dla opracowania nowej wersji tego Schematu powołał specjalną komisję. Zob. Secretarii generalis monitum. AS, vol. I, pars III, 259: „Quam ob rem necessarium videtur, propositum schema is defectibus expoliendum esse, de quibus solemnis hic coetus disceptare pergit, quin ad optatam conclusionem deveniat. Augustus Pontifex, ratione habita harum sollicitudinis causarum, atque plurium optatis annuens, 
ną one świadectwem tego, co Kościół na etapie przygotowań do Vaticanum II o sobie myślał i jak się zamierzał zreformować. W szczególności nie wolno tutaj pomijać milczeniem faktu, że cały szereg wysuniętych w Schematach propozycji stało się rzeczywiście treścią nauczania soborowego.

W kwestii sakramentalnego ,charakteru” Kościoła, która nas głównie interesuje, największe znaczenie posiadają Schematy o Kościele, o świętej liturgii i o ekumenizmie katolickim. Dlatego każdy z nich będzie odrębnie przeanalizowany. Inne Schematy tego tematu właściwie nie podjęły. Swoją koncepcją Kościoła niekiedy go tylko sygnalizują. Dla tej racji omówimy je łącznie. Ustalenia, do jakich dojdziemy tą drogą, pozwolą nam przede wszystkim skonstatować sam fakt występowania pod różnymi postaciami sakramentalnej koncepcji Kościoła w przygotowanych Schematach soborowych. Z kolei pozwoli to także na bliższe określenie tejże koncepcji do nauczania soborowej dokumentacji przedprzygotowawczej w tym względzie i miejsca, jakie organy przygotowujące Vaticanum II, Komisje i Sekretariaty, wyznaczały jej w dziele reformy Kościoła zamierzonej w II Soborze Watykańskim.

Ten sam temat - eklezjalnej sakramentalności — w okresie przygotowawczym do Vaticanum II, według posiadanych przez nas danych, podjął dotychczas tylko L. Boff ${ }^{17}$. Należy jednak od razu stwierdzić, że naszkicowane przezeń ujęcie problemu jest bardzo fragmentaryczne odnosi się tylko do schematów Konstytucji o Kościele i Liturgii świętej - i co najważniejsze, oparte na tekstach w znacznej mierze nie reprezentatywnych dla analizowanych dokumentów. Wiadomo bowiem, że geneza dokumentów soborowych zna różne teksty. Wartość ich jest także różna w zależności od źródła, z którego się wywodzą. Wszakże szczególne znaczenie posiadają te, które są rezultatem prac kompetentnych organów soborowych. Rzecz zrozumiała, że i one powinny być oceniane bardzo indywidualnie w każdym przypadku. Niemniej, nie wolno nigdy tekstów roboczych, które ostatecznie przez upełnomocnione do działania Komisje zostały zmienione lub nawet porzucone, uważać za definitywny wyraz ich zamierzeń. A tak właśnie - jak to zobaczymy - uczynił L. Boff odnośnie prac Komisji teologicznej w nauce o Kościele oraz, $i$ to jeszcze w większym stopniu, Komisji liturgicznej. Nadto, L. Boff w ogóle nie bierze pod uwagę prac Komisji centralnej. Stąd nasze ujęcie problematyki sakramentalnej koncepcji Kościoła w okresie przygotowań

benigne statuit rem speciali commissioni examinandam committere, quam component quidam em. mi Patres cardinales atque sodales sive commissionis theologicae sive secretariatus ad unitatem christianorum fovendam. Huius vero commissionis munus erit schema emendare, idemque brevius reddere atque magis apte perficere, principiis praesertim generalioribus instando".

${ }_{17}$ I. Boff, Die Kirche als Sakrament im Horizont der Welterfahrung, Paderborn 1972,$231 ; 234-237,238-242$. 
II Soboru Watykańskiego, opierając się na dokumentacji rzeczywiście reprezentatywnej dla tego etapu, jest nie tylko czymś zasadniczo nowym, lecz także, $\mathrm{z}$ metodologicznego punktu widzenia, jedynie słusznym podejściem do całego zagadnienia.

\section{TEANDRYZM EKLEZJALNY W SCHEMACIE KONSTYTUCJI DOGMATYCZNEJ} O KOŚCIELE

Omawiając sakramentalny wymiar eklezjologii Schematu o Kościele, przygotowanego przez Komisję teologiczną, pragniemy w pierwszej kolejności ustosunkować się do tego, co na ten temat napisał już L. Boff ${ }^{18}$. Otóż, na uwagę zasługują u niego głównie informacje, jakie podaje o pracach samej Komisji teologicznej, jak i jej Podkomisji De Ecclesia. Mimo swej wycinkowości, rzucają one nieco światła na nasze zagadnienie. Ale równocześnie musi się stwierdzić, że tekst przezeń zrelacjonowany, będąc tylko częścią jednego $\mathrm{z}$ roboczych projektów i to niektórych tylko teologów, nie wyraża pełnego i definitywnego stanowiska Komisji teologicznej w interesującej nas kwestii. Stanowisko to zawiera się bowiem dopiero w Schemacie o Kościele ${ }^{19}$ i w złożonych don Relacjach Kard. A. Ottavianiego, przewodniczącego Komisji teologicznej w czasie obrad Komisji centralnej ${ }^{20}$. Tymczasem o tych właśnie tekstach $\mathrm{L}$. Boff jakby nic nie wiedział. W każdym razie nie cytuje ich, a nawet nie czyni żadnej wzmianki. Nadto, ostateczny Schemat Komisji teologicznej, który wszedł pod obrady Soboru, zreformowany przezeń odrębnie, był już tekstem zmodyfikowanym po dyskusji i głosowaniu na Komisji centralnej ${ }^{21}$. Pragnąc odtworzyć pogląd Komisji teologicznej w całości wziętej na sakramentalność eklezjalną, trzeba więc zapoznać się z doktryną obu wymienionych dokumentów.

18 Tamże, 238-242.

19 De Ecclesia. Pars prima: Cap. 1: De Ecclesiae militantis natura; Cap. 2: De mebris Ecclesiae militantis eiusdemque necessitate ad salutem; Cap. 3: De episcopatu ut supremo gradu sacramenti ordinis et de sacerdotio; Cap. 4: De episcopis residentialibus; Cap. 5: De statibus evangelicae adquirendae perfectionis; Cap. 6: De laicis. Commentarius.

Pars secunda: Cap. 7: De Ecclesiae magisterio. Commentarius. Cap. 8: De auctoritate et oboedientia in Ecclesia; Cap. 9: De relationibus inter Ecclesiam et Statum necnon de tolerantia religiosa; Cap. 10: De necessitate Ecclesiae annuntiandi Evangelium omnibus gentibus et ubique terrarum; Cap. 11: De oecumenismo. SP, vol. III, pars I, 135-204.

20 Rozdziały I-VI zostały przedyskutowane przez centralną Komisję przygotowawczą w dniach 8-9 maja 1962 r., podczas szóstej sesji na piątym i szóstym posiedzeniu plenarnym. SP, vol. II, pars III: Sessio Quinta: 26 Martii - 3 Aprilis 1962; Sessio sexta: 3-12 Maii 1962, TPV 1968, 986-1115. — Z kolei rozdzialy VII-X były dyskutowane od 19-20 czerwca 1962 r., podczas siódmej sesji na siódmym i ósmym posiedzeniu plenarnym. SP, vol. II, pars IV, 621-746. - Wreszcie rozdział XI Komisja centralna przedyskutowała 20 czerwca 1962 r., podczas siódmej sesji na dziewiątym posiedzeniu plenarnym. Tamże, 792-812. 


\section{A. Schemat o Kościele}

Schemat o Kościele (De Ecclesia) Komisji teologicznej dzielił się na dwie części (pars): I część obejmowała rozdziały I-VI, część II rozdziały VII-XI; w sumie całość liczyła jedenaście rozdziałów ${ }^{22}$. Dokument ten był owocem długiej i żmudnej pracy. Wystarczy powiedzieć, że opracowująca go Podkomisja De Ecclesia odbyła aż 80 długich posiedzeń. Tekst przedstawiony Komisji centralnej przeszedł przez wiele poprawek i redakcji, spowodowanych interwencjami dużej części członków i biegłych całej Komisji teologicznej. Mimo to, tylko niektóre jego partie zostały przyjęte jednomyślnie ${ }^{23}$.

Wydaje się, że o podziale tego Schematu na dwie części zadecydowały względy merytoryczne. W części I mamy bowiem to, co się zwykło niekiedy nazywać esse - bytem Kościoła, a w części II jest raczej mowa - jego operari, czyli działaniu. Tematycznie ważna dla nas jest przede wszystkim część I. Poszczególne rozdziały traktują tutaj o naturze (I), członkach i konieczności zbawczej Kościoła (II), o sakrze biskupiej, jako najwyższym stopniu święceń i o kapłaństwie (III), o biskupach rezydencjalnych (IV), o zakonnikach (V) i katolikach świeckich (VI). Jak widać, część ta zbiera i przedkłada zasadnicze elementy stanowiące o rzeczywistości i podstawowej misji Kościoła. Natomiast problematyka dalszych rozdziałów na temat Magisterium kościelnego (VII), władzy i posłuszeństwa w Kościele (VIII), wzajemnych relacji pomiędzy Kościołem i państwem oraz wolności religijnej (IX), obowiązku głoszenia Ewangelii wszystkim narodom na całej ziemi (X), ekumenizmu (XI), objęta częścią

:1 Schema Constitutionis dogmaticae de Ecclesia. AS, vol. I, pars IV, 12-91. Tekst ten został rozdany Ojcom soborowym podczas 25 posiedzenia plenarnego 23. XI. 1962 r. Por. tamże, 12: Sacrosanctum Oecumenicum Concilium Vaticanum Secundum. Schemata Constitutionum et Decretorum de quibus disceptabitur in Concilii sessionibus. Series secunda: De Ecclesia et de B. Maria Virgine, TPV 1962. $\mathrm{Na}$ początku tego fascykułu widniała notatka: „Ss.mus Dominus noster Johannes Pp. XXIII, in audientia hoc die infrascripto impertita, statuere dignatus est ut haec Constitutionum et Decretorum schemata, in Concilio Oecumenico Vaticano secundo discutienda, ad eiusdem Concilii Patres transmittantur. Ex Aedibus' Vaticanis, die $\mathrm{X}$ mensis novembris anno MCMLXII. Hamletus Joannes card. Cicognani, a publicis Ecclesiae negotiis".

22 Por. przypis 19.

23 Relatio Em.mi P. D. Alfredi Card. Ottaviani, Praesidis Commissionis Theologicae, SP, vol. II, pars III, 995 oraz SP, vol. II, pars IV, 635, gdzie czytamy: „Ut iam antea dictum est in hac aula, Subcommissio de Ecclesia, ad opus suum explendum, 80 habuit sessiones; et auditis observationibus magni numeri tam consultorum quam membrorum, Commissio theologica plenaria hanc secundam partem post unius hebdomadae sessiones matutinas et vespertinas, non sine discussionibus, definitive approbavit, exceptis quibusdam quae novo studio commendavit Subcommissionis. Nonnulla capita sexies vel septies fuerunt reformata (quod etiam valet de parte prima)". W Relacji odnotowanej w: SP, vol. II, pars III, 995 jest mowa tylko o 75 posiedzeniach. 
II, dotyczy w zasadzie konkretnych przejawów życia Kościoła, a więc jego autorealizacji ${ }^{24}$.

a. Na pytanie, czym jest Kościół, znajdujemy zatem odpowiedź w I rozdziale omawianego Schematu, zatytułowanym: „Natura wojującego Kościoła" 25.

Kościół - stwierdza się tam - ma swój początek w odwiecznym planie zbawczym Boga, realizowanym przez Całą Trójcę Przenajświętszą: Ojca (Kol 1, 13; 6a 4; 4), Syna (1 T 2, 14) i Ducha Świętego (Hbr 9. 14). Spodobało się bowiem Ojcu, aby ludzie przez Syna w Duchu Świętym zbawiali się nie pojedynczo, lecz stanowiąc ,nowe plemię wybrane”, „,królewskie kapłaństwo”, ,święty naród”, czyli „,nowy Izrael Boży” (por. 1 P 2, 9; Ga 6, 16). Szczególne zadanie w dziele realizacji tego Bożego planu zbawczego przypadło na świecie Synowi Bożemu, który stawszy się człowiekiem ( $\mathrm{J}$ 1, 14; Flp 2, 7-8), jako Nauczyciel (Mt 23, 8-10; J 13, 13-14), Kapłan (Hbr 4, 14; 5, 10; 9, 11-14) i Król (自 23, 3; J 18, 37) prowadzi obecnie do zbawienia lud Boży (1 P 2, 10) z pomoca posłanych przez siebie przełożonych, wyposażonych w jego własne prerogatywy nauczania, uświęcania i rządzenia (Mt 28, 18-20; Mk 16, 15-16). Lud ten nie jest zatem jakąś ,,bezkształtną masą" (effusa turba), lecz ,zwartym oddziałem" (confertum agmen), który zwycięsko oprze się zakusom diabła (Mt 16, 18; Ef 6, 11) i przetrwa aż do końca świata. Lud Boży Starego Przymierza, również zwany Kościołem Bożym (Lb 20, 4; Pwt 23, 2) był tylko figurą Kościoła Chrystusowego, nabytego przez Zbawiciela wylaną krwią na krzyżu (Dz 20, 28; Ef 2, 15-16), a zbudowanego na Piotrze i jego następcach (Mt 16, 18). W Piśmie św. bywa on nazywany między innymi: „,królestwem” (Mt 16, 19), „domem” (1 Tm 3, 15), „świątynią Boga" (1 Kor 3, 16; 2 Kor 6, 16; Ef 2, 21), ,stadem” albo ,owczarnią" ( J 10, 16; 21, 15-17; 1 P 5, 2-3; Łk 12, 32; Mt 26, 31), ,oblubienica Chrystusa" (Ap 21, 9; 22, 17; Ef 5, 22-32; por. Mt 9, 15; Mk 2, 19; Łk 5, 34; J 3, 29), „filarem i podporą prawdy” (1 Tm 3, 15), Matką (Ga 4, 26), które to nazwy ukazują zarówno społeczny, jak i mistyczny aspekt jego natury.

Wśród tych nazw naczelne miejsce zajmuje figura Ciała Chrystusa, którą posłużył się św. Paweł. Chrystus jest „Głową Ciała Kościoła” (Kol 1, 18), który jako Jego Ciało stanowi ,,pełnię tego, który napełnia wszystko na wszelki sposób" (Ef 1, 23). Ci, którzy przez chrzest weszli do Ko-

24 W dwóch Relacjach Kard. A. Ottavianiego, odczytanych przez S. Trompa, sekretarza Komisji teologicznej, są podane także nazwiska autorów niektórych rozdziałów Schematu De Ecclesia. I tak, rozdz. II pisali: Sekretarz, bpi Dubois i Franić, oraz teolodzy Fenton, Philips, Schmaus, Balić, Brinktrine, Congar (SP, vol. II, pars III, 997); o biskupach (rozdz. III i IV) napisali: bp Dubois oraz teolodzy Schauf, Maccarone, Congar, Léucyer i Sekretarz (tamże, 1048).

${ }_{25}$ SP, vol. II, pars III, 986-990 (Schema propositum a Commissione Theologica. Cap. 1. De Ecclesiae militantis natura). 
ścioła (por. J 3, 5) i przyodziali się w Chrystusa (por. Ga, 27), mając uczestnictwo w jednym chlebie eucharystycznym, osiągają doskonałość w jedności jednego Ciała (por. J 17, 23). Ze względu bowiem na jeden chleb „,tworzą jedno ciało” (1 Kor 10, 17). Tak więc, Kościół-społeczność jest mistycznym Ciałem Chrystusa. Niesłusznie zatem Kościół hierarchiczny lub prawa bywa niekiedy oddzielany od Kościoła charyzmatycznego czy miłości. W istocie różnicy tu nie ma, ponieważ Kościół społeczność i Mistyczne Ciało Chrystusa nie są bynajmniej dwiema rzeczami, lecz jedna rzeczywistością, która odznacza się ludzkim i boskim aspektem i stąd, Kościół może być porównany przez analogię z misterium Wcielonego Slowa. ,Albowiem jak w Słowie Wcielonym natura ludzka służyła za narzędzie jego boskiej natury dla naszego i całego świata zbawienia, i w niebie nadal nie przestaje służyć, tak społeczność Kościoła została wyposażona w charyzmaty zwiastuna, kapłana i króla, aby służyć Duchowi Chrystusa w budowaniu Ciała Chrystusowego; te bowiem charyzmaty, podobnie zresztą jak i inne, otrzymywane od Ducha Swiętego, powinno się sprawować jako posługę oraz urząd prawdy i miłości, by zdobyte przez Chrystusa zbawienie, wraz ze wszystkimi dobrodziejstwami, jakie stad się wywodzą, spłynęły na wszystkich ludzi i wszystkie czasy" 26. Sobór ma wyznać, że za prawdziwy Kościół Jezusa Chrystusa, który jest czczony w wyznaniu wiary jako jeden, święty, katolicki i apostolski słusznie (iure) uważa się jedynie Kościół Rzymsko-katolicki.

W Relacji złożonej przed Komisją centralną, Komisja teologiczna wskazała jeszcze na dwie naczelne idee, które leżą u podstaw naszkicowanej koncepcji Kościoła: po pierwsze, że Chrystus pragnął naszego zbawienia przez zjednoczenie każdego człowieka ze swoją osobą teandryczna (persona theandrica), co tutaj na ziemi dokonuje się w społecznym organizmie Kościoła oraz po drugie, że nie istnieje żadna różnica realna pomiędzy widzialnym Kościołem rzymsko-katolickim i tym Kościołem, który jest Mistycznym Ciałem Chrystusa. Kościół widzialny i Mistyczne Ciało Chrystusa są bowiem jedną i tą samą rzeczą rozpatrywaną tylko z różnych punktów widzenia. Dlatego Kościół we właściwym znaczeniu słowa (vero sensu) mógłby być nazwany teandrycznym (theandra). Określeniem tym jednak nie posłużono się, aby uniknąć zbyt technicznych

26 Tamże, 988: „Etenim sicut in Verbo Incarnato natura humana ut vivum instrumentum divinae eiusdem naturae, pro nostra et totius mundi salute inserviit et in coelis inservire perseverat, ita Ecclesiae societas praeconis, sacerdotis, regis charismatibus exornatur, ut Spiritui Christi in aedificatione Corporis Christi serviat; haec enim charismata, non aliter atque cetera quae a $S$. Spiritu tribuuntur, tanquam veritatis et charitatis servitium ministeriumque exercenda sunt, ut parta per Christum salus simulque beneficia, omnia quae inde proficiscuntur, in omnes homines atque ad omnes aetates propagentur". - Załącznik 45 do tego tekstu cytuje: „Pius IX, La Chiesa di Dio, 2 marzo 1871, A.S.S., Vol. VI (1970), p. 267; Leo XIII, Satis cognitum, A.S.S., 28 (1895-96), p. 710; S. Thom., In Eph., cap. 4, lect. 4; Quodlib. VII, q. 6, a. 2, ad 5". Tamże, 990. 
rozważań na temat analogiczności tego pojęcia względem teandrycznego Chrystusa (Christi Theandri) ${ }^{27}$.

Nie wchodząc bliżej w ocenę co dopiero naszkicowanej wizji Kościoła i calej dyskusji, jakiej została poddana, pragniemy tutaj tylko stwierdzić, że $z$ metodologicznego punktu widzenia była ona dużą nowością. Podstawą, którą wzięła za punkt wyjścia, są bowiem dane Objawienia, a nie uprzednio stworzona ludzka idea ogólna. I choć dalsze prace soborowe wiele $\mathrm{w}$ niej zmieniły, to jednak pozostały wierne temu podstawowemu założeniu. Nie bez znaczenia pozostaje również fakt, że tę biblijną koncepcję Kościoła postawiono na czele w I rozdziale, jako wprowadzenie w całą pozostałą problematykę eklezjologiczną.

Obrazy, użyte w tekście, mocno akcentowały charakter chrystologiczny, soteriologiczny i eschatologiczny Kościoła. Wśród nich szczególnie blisko związany z ideą Kościoła-Sakramentu, był stary tytuł KościołaMatki (Ecclesia Mater). Najważniejsze wszakże dla niej jest tam to, co zostało powiedziane na temat wzajemnej współzależności istniejącej pomiędzy społeczną strukturą Kościoła i oddziaływaniem nadprzyrodzonych darów i charyzmatów, a mianowicie, że pomiędzy tajemnicą Słowa Wcielonego i tajemnicą Kościoła istnieje „nie mała analogia” (ob analogiam non parvam), ponieważ $w$ obu misteriach pozostaje nierozdzielnie złączony element boski i element ludzki, i to w taki sposób, że to, co ludzkie, służy temu, co boskie jako znak i narzędzie zbawienia. Tym samym, Schemat o Kościele równoważnie uczynił własnym tradycyjny pogląd teologii, uznający Chrystusa za podstawowy sakrament, w którym człowieczeństwo Syna Bożego jest najdoskonalszym narzędziem łaski i stwierdzający zarazem, że Kościół także posiada tę samą sakramentalną strukturę. W ujęciu tym, sakramentalność Chrystusa, wcielenie Syna Bożego, stanowi ostateczną podstawę sakramentalności eklezjalnej, wiążącej niewidzialną łaskę $\mathrm{z}$ widzialną rzeczywistością Kościoła i jego sakramentów.

b. Również dalsze rozdziały I części Schematu o Kościele zawierały naszym zdaniem - ważne elementy dla sakramentalnej koncepcji Kościoła.

Rozdział II: „Członkowie Kościoła wojującego i jego konieczność do zbawienia", akcentując eklezjalne aspekty sakramentu chrztu, zwłaszcza uzyskiwane z nim członkostwo Kościoła, czynił Kościół na równi z tymże chrztem, koniecznym środkiem zbawienia. „Jak bowiem nikt nie może się zbawić, jak tylko przez faktyczne (re), lub pragnieniem (voto), przyjęcie chrztu, który człowieka nie sprzeciwiającego się włączeniu czyni członkiem Kościoła, tak samo nie osiągnie się zbawienia bez bycia rze-

27 SP, vol. II, pars III, 995-996 (Relatio Em. mi P. O. Alfredi card. Ottaviani, Praesidis Commissionis Theologicae). 
czywiście członkiem Kościoła lub bez przyporządkowania się doń pragnieniem" ${ }^{28}$. W Relacji Komisja teologiczna wyjaśniała nadto, że pomiędzy dziećmi Kościoła i odłączonymi braćmi nie ulegają zniszczeniu wszyśtkie więzi: Ktokolwiek został poprawnie (rite) ochrzczony, ten staje się nawet niechcąco (etiam invitus) poddanym Kościoła. Co więcej, dzięki wspólnej wierze w Chrystusa i przyjmowaniu sakramentów istnieją pomiędzy katolikami i nieświadomymi odszczepieńcami więzi, które zdecydowanie wykraczają poza porządek prawny: odłączeni bracia żyją w stanie łaski i pozostają złączeni z dziećmi Kościoła, uświęconymi stanem łaski, świętych obcowaniem (communione sanctorum) ${ }^{29}$. - Stwierdzenia te niewątpliwie stoją na gruncie prymatu struktury sakramentalnej nad porządkiem prawnym w Kościele. Życie Boże, rozlewające się mocą sakramentów na wierzących w Chrystusa, łączy ich między sobą w tajemniczy a zarazem realny sposób, mimo wszystkich dostrzegalnych rozbieżności.

Z rozdziału III: „Episkopat jako najwyższy stopień sakramentu święceń i kapłaństwo”, oraz z rozdziału IV: „Biskupi rezydencjalni”, należy odnotować głównie tezę, że ,episkopat jest prawdziwie i w znaczeniu właściwym najwyższym stopniem sakramentu święcen" ${ }^{30}$ oraz, że biskupi rezydencjalni swoją aktualną jurysdykcję otrzymują również dzięki sakrze (ordinatione sacra), a nie tylko poprzez misję prawną (missione iuridica) ze strony kierownictwa Kościoła, tj. następcy Piotra, i wreszcie że kolegium biskupie wraz $\mathrm{z}$ biskupem Rzymu jest podmiotem pełnej i najwyższej władzy w Kościele. Dzięki powyższym stwierdzeniom, sakra biskupia została ukazana jako istotny czynnik składowy całego ustroju hierarchicznego Kościoła. Wprawdzie wiele kwestii zostało tutaj przemilczanych lub niedopowiedzianych, jak np. problem biskupów nierezydencjalnych czy pozytywne związanie sakry biskupiej z władzą jurysdykcji wziętą indywidualnie i kolegialnie, ale trzeba też lojalnie powiedzieć, że tej ostatniej kwestii nie proponowano rozstrzygać po linii tendencji zmierzających do ich całkowitego rozdzielenia. Opowiadając się przy sprawowaniu władzy biskupów rezydencjalnych za poddaniem tejże biskupowi Rzymu, Schemat nigdzie bowiem nie mówił, że papież bezpośrednio ją daje. Stwierdza jedynie, że względem całego Kościoła poje-

28 „Sicut autem nemo salvari potest, nisi sive re recipiat Baptismum, quo quis non ponens obicem incorporationis, fit membrum Ecclesiae, sive Baptismi voto, sic nemo salutem obtinere valet, nisi membrum Ecclesiae reapse exsistat, vel voto ad eandem ordinetur", SP, vol. II, pars III, 990 (Schema propositum a Commissione Theologica. Caput 2. De membris Ecclesiae Militantis eiusdemque necessitate ad salutem).

29 Tamże, 997 (Relatio Em.mi P. D. Alfredi Card. Ottaviani, Praesidis Commissionis Theologicae).

30 ,Dubitare nemo debet episcopatum esse vere et proprie gradum supremum Sacramenti Ordinis". Tamże, 1038 (Schema propositum a Commissione theologica. Caput 3. De episcopatu ut supremo gradu sacramenti ordinis et de sacerdotio). 
dynczy biskup ma troskę (sollicitudo) a nie władzę (potestas). Władzę taką posiadają wszakże biskupi razem wzięci, czyli jako ciało lub kolegium. W gestii głowy kolegium pozostaje tylko jej sprawowanie (exercitium) ${ }^{31}$. - Wszystkie przytoczone niedopowiedzenia czy braki nie pomniejszają wszakże znaczenia samej myśli uznania święceń episkopatu za sakrament. Raz powzięta, ukazała sakrament święceń jako fundament konstytucji hierarchicznej Kościoła i w ten sposób stworzyła na tym odcinku możliwość rozstrzygnięcia wielu dyskusyjnych problemów w kwestii sakramentalności eklezjalnej.

Również „Stany doskonałości ewangelicznej” zostały w rozdziale V przedstawione w perspektywie tejże sakramentalności eklezjalnej. Jak zaznacza Relacja, Komisja teologiczna starała się pokazać, w jaki sposób są one „rzeczami Ciała Mistycznego" 32. I tak, rady ewangeliczne maja pochodzenie boskie, a ich realizacja współkonstytuuje znamię świętości Kościoła. Życie bowiem tych, którzy idą za nimi pod działaniem łaski Chrystusa, przyczynia się do tego, że właśnie to znamię dane przez boskiego Założyciela Kościołowi, stale jaśnieje na oczach wszystkich. Stąd droga ewangelicznych rad pozostaje w głębokiej harmonii z podstawowym zadaniem Kościoła: dawaniem Boga ludziom i ofiarowywaniem się ludzi swojemu Bogu. Jednym słowem, stanowi współrealizację zbawczej misji Kościoła. Ale rady ewangeliczne należy i dlatego cenić, ponieważ czynią człowieka podobnym do Chrystusa i Kościoła, zjednoczonego najściślej ze swoim Oblubieńcem i będącego dla wszystkich narodów widzialnym portem zbawienia. Owo podobieństwo do Chrystusa, który także był najdoskonalszym człowiekiem, i do jego świętego Kościoła, spoleczności ludzkiej i boskiej zarazem, ukazuje wartość rad ewangelicznych dla pełnego rozwoju osoby ludzkiej ${ }^{33}$. - W ujęciu tym rady ewangeliczne stanowią istotne realia świętości zbawczej Kościoła. Na swój sposób świętość tę nie tylko oznaczają, lecz także sprawiają.

Rozdział VI: „O świeckich” ukazuje wreszcie Kościół jako powołany przez Chrystusa do wiecznej realizacji dzieła odkupienia ${ }^{34}$. W Kościele

31 Por. tamże, 1047-1048 (Relatio Em.mi P. D. Alfredi Card. Ottaviani, Praesidis Commissionis Theologicae).

32 ,Quare Commissioni Theologicae curae fuit clare describere ea quibus appareat quomodo consilia evangelica sint iuxta verba theologorum Vaticani I res Corporis Mystici". Tamże, 1095 (Relatio Em.mi P. D. Alfredi Card. Ottaviani, Praesidis Commissionis Theologicae).

3:3 „Haec autem conformitas cum Christo, qui homo etiam perfectissimus fuit, atque assimilatio Ecclesiae suae sanctae, quae societas est non modo humana verum etiam et divina, sat superque ostendunt statum perfectionis, nedum personae humanae profectui obstare, immo summopere eidem prodesse". Tamże, 1085 (Schema propositum a Commissione theologica. Caput 5. De statibus evangelicae adquirendae perfectionis), Tamże, 1085. Por. tamże, 1084.

34 Mamy tutaj zacytowany początek Konstytucji Pastor aeternus I Soboru Watykańskiego, który jest jedynym tekstem tego Soboru, wskazującym na sakramentalny charakter Kościoła: „Pastor aeternus et episcopús animarum nostrarum 
wszyscy bez wyjątku wierni złączeni jedną wiarą i miłością pod kierownictwem pasterzy mają czynnie działać. Obowiązkiem ich bowiem jest skuteczne spełnianie na świecie zbawczego planu Bożego. Wzrostowi i stałemu uświęcaniu Kościoła powinni oddawać zatem swoje siły naturalne i nadprzyrodzone. Uprawnia ich do tego odrodzenie chrzcielne i namaszczenie Duchem Świętym, dzięki któremu posiadają wraz z kapłanami i zakonnikami powszechne kapłaństwo, różniące się od kapłaństwa ministerialnego nie stopniem, lecz co do istoty. Uczestnicząc na swój własny sposób w urzędzie kapłańskim, prorockim i królewskim Chrystusa kontynuują zarazem jego zbawczą misję. Misja świeckich, mimo całego swego zróżnicowania, w porównaniu z funkcją przedstawicieli hierarchii i życia zakonnego w gruncie rzeczy zmierza do tego samego celu, ponieważ to samo jest powołanie całego organizmu Kościoła. Jednym z zadań katolików świeckich jest ,konsekracja świata”, zmierzająca do, przesycenia Duchem Chrystusa wszystkich odcinków ludzkiego działania i postępu, a nawet pomagająca wyjść światu poza swój porządek świecki ${ }^{35}$. - Stosownie do tego, co zostało zreferowane, katolicy świeccy, podobnie jak hierarchia, na swój sposób są ubogaceni godnością kapłaństwa Chrystusowego do realizacji misji Kościola. Daje im to nie tylko przywilej do korzystania $\mathrm{z}$ dzieła zbawczego Chrystusa, ale także zobowiąuje ich do świadczenia i przekazywania go innym.

Jak widać, również dalsze rozdziały Schematu o Kościele kryją w sobie zasadniczo sakramentalną koncepcję Kościoła. Kościół tutaj dla każdego jest koniecznym środkiem zbawienia. Nie jest on jednakże tylko jakimś narzędziem - rzeczą lub czymś, co by przypominało zbiorowisło rzeczy bezładnie nagromadzonych. Stanowią go żywi ludzie złączeni między sobą różnymi więzami, zwłaszcza darem łaski, w jedną mistyczną osobę (una mystica persona). W swoim istotnym zróżnicowaniu dar ten bliżej określa miejsce i rolę obdarowanych we wspólnocie Kościoła. Posiadanie go, zdobyte przede wszystkim za pośrednictwem sakramentów świętych, sprawia, że teandryzm Chrystusa znajduje w jakiejś mierze swoje odbicie i realizację w przebóstwionym podmiocie ludzkim. Na skutek tego wszyscy bez wyjątku członkowie Kościoła - hierarchia, zakonnicy, katolicy świeccy — ożywieni Duchem Chrystusa nie tylko partycypują w sakramentalnej strukturze Kościoła, lecz także ją realizują i obwieszczają światu.

(1 Petr 2, 25), ut salutiferum redemptionis opus perenne redderet, sanctam aedificare Ecclesiam decrevit". DS 3050. Por. SP, vol. II, pars III, 1087-1091 (Schema propositum a Commissione theologica. Caput 6. De laicis).

${ }_{35}$,Ad laicos denique pertinet consecratio mundi, id est actio ut mundus in omni campo suae activitatis suique progressus Spiritu Christi imbuatur, quin ex proprio suo ordine exeat saeculari". Tamże, 1089. przypis 8 cytuje do tego tekstu: „Pius XII, Alloc. Six ans se sont écoulés, 5 oct. 1957, A.A.S., 49 (1957), p. 927". 


\section{B. Schemat Konstytucji dogmatycznej o Kościele}

a. Schemat Konstytucji dogmatycznej o Kościele (Schema Constitutionis dogmaticae de Ecclesia) był drugą - o czym już wzmiankowaliśmy - wersją problematyki eklezjologicznej w opracowaniu przygotowawczej Komisji teologicznej łącznie z Podkomisją Komisji centralnej, powołanej do poprawek Schematów zgodnie z zaleceniami tejże Komisji centralnej. Niestety, w dotychczasowej literaturze soborowej uderza brak poważniejszego studium na temat prac przygotowawczych Komisji centralnej. Tu i ówdzie można o nich spotkać tylko lakoniczne wzmianki. Odnosi się to również do stanowiska, jakie Komisja centralna zajęła względem Schematu o Kościele ${ }^{36}$.

Obrady Komisji centralnej nad Schematami przebiegały według ściśle określonego porządku. Najpierw miała miejsce krótka dyskusja (animadversiones), a później następowało głosowanie (suffragia) według klucza: „tak” (placet), „nie” (non placet), „tak z zastrzeżeniem” (placet iuxta modum), z tym że przy tej okazji członkowie Komisji (sodales) wypowiadali jeszcze jakieś swoje życzenia, czy uwagi merytoryczne. Stąd głosowanie było bardziej kontynuacją dyskusji, niż „czystym” głosowaniem za przyjęciem lub odrzuceniem tekstów.

W związku z debatą nad Schematem o Kościele dowiadujemy się o dysonansie, jaki zaistniał na tle problemów eklezjologicznych pomiędzy Sekretariatem dla jedności chrześcijan i Komisją teologiczną. Rzecz szła o powolanie przez te dwa organy Komisji mieszanej do ich rozpatrzenia. Propozycja wyszła od Sekretariatu dla jedności chrześcijan ze względu na olbrzymią wagę problemów eklezjologicznych nie tylko dla katolików, lecz także dla wszystkich chrześcijan ochrzczonych ${ }^{37}$. Komisja teologiczna, stojąc na stanowisku, że kwestie doktrynalne należą do jej wyłącznej kompetencji i wszystkie inne Komisje na tym odcinku swej działalności podlegają jej kontroli, sprzeciwiła się temu ${ }^{38}$. Z perspektywy lat, dzisiaj

${ }^{36}$ Np. C. Caprile, Il Concilio Vaticano II. Cronache del Concilio Vaticano II edite da "La Civilta Cattolica”. L'annunzio a la preparazione 1959-1962, vol. I, parte II: 1961-1962, Roma (bdw), 434; 500-501. - Constituzione dogmatica sulla Chiesa, w: Dizionario del Concilio ecumenico Vaticano II, Roma 1969, 126. - U. Betti, Histoire chronologique de la Constitution, w: LEglise de Vatican II (Unam Sanctam, 51 b), t. II, Paris 1966, 60.

${ }_{37}$ (Card. Bea). „Inter quaestiones a Concilio tractandas hae quae de Ecclesia proponuntur, certe maximi momenti sunt, idque non solum pro Catholicis, sed etiam pro omnibus christianis baptizatis, sed ab Ecclesia separatis. Ideo Secretariatus pro fovenda Unione Christianorum has quaestiones valde accurate tractavit et pluries etiam a Commissione theologica petivit, ut Commissio mixta instituatur, id quod tamen semper refutatum est. Quare schemata a nobis elaborata Commissioni theologicae transmisimus, et grato animo animadverti aliqua saltem vestigia inveniri in Schematibus Commissionis, etsi, proh dolor, satis multa considerata non sunt". SP, vol. II, pars III, 1012.

"3s „Card. Ottaviani: Primo quidem debeo ponere in tuto quod non admitto Commissionem theologicam debere agere cum aliis Commissionibus in is quae sunt 
nie ulega wątpliwości, że wiele sporów wokół Schematu eklezjologicznego w czasie obrad Komisji centralnej, a później na auli soborowej, tutaj właśnie miało swoje źródło.

Sam Schemat o Kościele był rozpatrywany przez Komisję centralną stopniowo, w kolejności po dwa rozdziały, za wyjątkiem jedenastego, który pozostał na końcu do samodzielnego zbadania. Istotne innowacje w tym porządku nastąpiły przy ostatnich rozdziałach. Sekretariat dla jedności chrześcijan przedstawił bowiem wiedy w odrębnych Schematach o wolności religijnej ${ }^{39}$ i o ekumenizmie katolickim ${ }^{40}$ własne ujęcie problematyki, pomieszczonej odpowiednio $w$ rozdziałach IX ${ }^{41}$ i XI ${ }^{42}$ Schematu o Kościele. Rozpatrywanie łączne tych tekstów doprowadziło do ostrej konfrontacji stanowisk w łonie Komisji centralnej, zwłaszcza w kwestii stosunków Kościoła z państwem oraz tolerancji religijnej ${ }^{43}$. Z dużymi zastrzeżeniami spotkało się również ujęcie problemu granic Kościoła i członkostwa w Kościele ${ }^{44}$.

Ogólnie zatem należy stwierdzić, że Schemat o Kościele nie będąe przez nikogo kwestionowany w swej zasadniczej koncepcji, napotkał jednak podczas obrad Komisji centralnej na dość duży sprzeciw co do niektórych swoich elementów, o czym najlepiej świadczy duża liczba poprawek proponujących ulepszenia. Stąd w głosowaniu przeważały głosy ,tak z zastrzeżeniem”. Głosów ,nie” prawie w ogóle nie było, a głosy

ad doctrinam. Commissio theologica in hac re est plena independens, quia agitur de doctrina et non agitur sicut in aliis Commissionibus in quibus fiunt res mixtae... Igitur possunt esse res quae tangunt Commissionem doctrinalem in aliis Commissionibus, sed debent remitti ad Commissionem doctrinalem et Secretarius pro uniendis acatholicis debuerat potius suum schema (...) mittere ad Commissionem doctrinalem ut videatur si esset concors cum Commissione doctrinali. Nunc videmus, quod sund quaedam in quibus non sumus concordes et non sumus concordes in rebus doctrinalibus". SP, vol. II, pars IV, 691.

${ }_{39}$ Tamże, 676--884 (De libertate religiosa).

40 Tamże, 785-792 (De oecumenismo catholico).

41 Tamże, 657-672 (De relationibus inter Ecclesiam et statum necnon de tolerantia religiosa).

42 Tamże, 792-800 (De oecumenismo).

43 O napiętej atmosferze obrad bardzo wymownie świadczy oświadczenie Kard. A. Ottavianiego złożone przed przystąpieniem do glosowania nad tą kwestią: „Ante omnia loquor ante suffragium ferendum et peto ut clare dicatur utrum placet... placet iuxta schema propositum a Commissione doctrinali, vel placet iuxta schema propositum a Secretariatu pro acatholicis... Et hoc omnino necessarium est, ut clare dicatur, qualis via eligenda sit, quia in hac re sunt multae... Igitur ne faciamus suffragia posita super aequivocationibus; et peto, ut fiant suffragia circa unum vel alterum schema, quia esset inutile constituere tertiam Commisionem, sicut quidam proposuerunt, si circa quaedam fundamentalia, sicut plures dixerent iuste, sunt fundamentales discrepantiae, et si non damus lineam; qualem lineam debemus tenere? Tunc quid faciet ista tertia Commissio, Litigabit! Sicut nos litigavimus istis diebus, heri et hodie! Igitur clare dicatis quid sentiatis". Tamże, 719-721. - Por. całość dyskusji i głosowanie w tej sprawie tamże, 684-746.

${ }_{44}$ W tym wypadku chodziło głównie o rozdziały I i II Schematu De Ecclesia zatytułowane odpowiednio: „De Ecclesiae militantis natura" i "De membris Ecclesiae militantis eiusdemque necessitate ad salutem". Por. SP, vol. II, pars III, 986-993; 997-1037 (passim). 
„,tak" w liczbie zauważalnej na równi z głosami warunkowymi, padły tylko pod adresem niektórych rozdziałów, a mianowicie: III, V, VII, VIII, X 45. Rzecz zrozumiała, że przy takim stanie rzeczy, zarówno Komisja teologiczna jak i Podkomisja Komisji centralnej, odpowiedzialne za ostateczny kształt Schematów, musiały się podjąć ponownego trudu celem uwzględnienia wniosków Komisji centralnej. Po wprowadzeniu rzeczywiście bardzo licznych poprawek, nowa wersja dokumentu eklezjologicznego otrzymała tytuł ,Konstytucji dogmatycznej o Kościele" 46. Jednakże należy tutaj od razu dodać, że nie spowodowały one prawie żadnych istotnych zmian w ogólnej kompozycji dawnego Schematu. Ilość i tytuły rozdziałów, a nawet w olbrzymiej większości układ akapitów pozostały te same. Został zniesiony tylko podział na części i wprowadzona ciągła numeracja paragrafów. Mimo to innowacje w większości przypadków nie miały charakteru merytorycznego; dotyczyły więcej strony formalnej tekstu, zwłaszcza stylu, niż problemów. W zasadzie, poza nielicznymi wyjątkami, nie ingerując w samą treść ${ }^{47}$, czyniły go jedynie bardziej czytelnym i pastoralnym.

b. Dla nas jednakże ważnym pozostaje przede wszystkim pytanie, czy .w dyskusji na Komisji centralnej został w jakiejś mierze podniesiony problem sakramentalnej struktury Kościoła i czy ulepszony Schemat Konstytucji dogmatycznej o Kościele wykazuje w tym względzie nowe sformułowania. Jeżeli na pierwszą część tak postawionego pytania odpowiedź jest pozytywna, to zarazem należy stwierdzić, że to, co tam powiedziano, nie znalazło dostrzegalnego odbicia w samym tekście wspomnianego dokumentu. Była to tym większa szkoda, że w grę wchodziły takie elementy, które później w czasie obrad soborowych trwale zostały związane z pojęciem Kościoła jako sakramentu, zwłaszcza kwestia jedności rodzaju ludzkiego w Chrystusie. Niemniej pozytywnie należy tutaj ocenić dalsze utrzymanie passusu rozdziału I-go, stwierdzającego teandryzm Chrystusa i Kościoła. Po tej samej linii poszło także nowe wyjaśnienie Komisji teologicznej w tej sprawie. „Rozdział I o naturze wojującego Kościoła - mówił Relator na auli soborowej - zmierza do tego, aby jasno pokazać, iż pomiędzy Ciałem mistycznym Chrystusa i widzialnym Kościołem, pomiędzy Kościołem jurydycznym a Kościołem pneumatycznym, jak się mówi, lub Kościołem miłości, nie ma żadnego realnego

45 Por. Suffragia sodalium: tamże, 1025-1037; 1066-1083; 1105-1115; SP, vol. II, pars IV , 648-656; 721-746; 807-812. Wymienione rozdziały były zatytułowane: III - „De episcopatu ut supremo gradu sacramenti ordinis et de sacerilotio"; V - „De statibus evangelicae acquirendae perfectionis”; VII - „De Ecclesiae magisterio"; VIII - „De auctoritate et oboedienta in Ecclesia”; IX - por. przypis 38.

46 Por. przypis 19.

47 Dotyczyło to głównie rozdziałów II, V i IX. 
rozdzielenia, lecz oba te terminy oznaczają tylko różne aspekty jednej i tej samej rzeczy" ${ }^{48}$.

Z samej dyskusji na Komisji centralnej odnotujemy jedynie kilka bardziej charakterystycznych dla naszej kwestii głosów. I tak, Kard. J. Döpfner oświadczył, że dyskutowany Schemat podejmuje problematykę, która w ostatnich dziesiątkach lat była przedmiotem bardzo gruntownych studiów teologicznych. Sobór powinien zebrać owoc tych poszukiwań i w ten sposób przedstawić naukę o Kościele, aby ten w obecnych, pełnych zaburzeń czasach stał się „,widocznym znakiem zbawienia”, w którym wszyscy będą odnajdywać pokój i nadzieję błogosławieństw. „W Kościele bowiem dalej trwa i aktualizuje się misterium Chrystusa, Głowy całej ludzkości i Centrum wszechświata”. To właśnie pokaże również, do jakiego stopnia idee jedności i uniwersalizmu, dzisiaj szczególniej ożywiające ludzi, właśnie tylko w Kościele mogą znaleźć prawdziwą swoją realizację ${ }^{49}$.

Do tych ostatnich myśli nawiązał także Kard. F. König, który żądał, aby w prologu Konstytucji o Kościele została umieszczona wzmianka o jedności rodzaju ludzkiego w jego boskim pochodzeniu i o ukazującej ją stopniowo historii, o ostatecznym przeznaczeniu człowieka, polegającym na uczestnictwie w wewnętrznym życiu Boga, o Słowie Wcielonym, podstawie zjednoczenia świata samego w sobie i z Bogiem, oraz „o Kościele jako znaku widzialnym i skutecznym, eschatologicznym, tej jedności i konsekracji świata" ${ }^{50}$.

Szczególniej cenne w kwestii sakramentalności eklezjalnej są uwagi Kard. A. Bea wyjaśniające, w jakim znaczeniu Kościół jest koniecznym środkiem zbawienia. Sam „dar zbawienia” (salutis donum) stanowi łaska, czyli życie Boga, które ludzie otrzymując stają się ,uczestnikami natury Bożej" (2 P 1,4). Pan Bóg udziela go jedynie tym, którzy są odpowiednio dysponowani, tzn. bądź przyjmują, bądź też są gotowi przyjąć zbawienie i środki do niego prowadzące. Faktyczne otrzymanie zbawienia jest bezwzględnie uwarunkowane posiadaniem wiary, ,że (Bóg) jest i że wynagradza tych, którzy Go szukają” ( $\mathrm{Hbr} 11,6)$. Natomiast „,́́rodkami zbawienia" (salutis media) ustanowionymi przez Boga są wiara, sakramenty, przykazania, pasterze, społeczność braci, jednym słowem wszystko to, co czyni Kościół „narzędziem zbawienia” (instrumentum salutis). Ten śro-

48 Relatio exc.mi P. D. Francisci Franić: „Cap. I, de Ecclesiae militantis natura, ad hoc tendit ut claris verbis ostendat inter corpus Christi mysticum et Ecclesiam visibilem, inter Ecclesiam iuridicam et Ecclesiam pneumaticam, uti dicunt, seu Ecclesiam caritatis, nullam esse distinctionem realem, sed istos terminos tantummodo diversos aspectus unius eiusdemque rei significare". AS, vol. I, pars IV, 122.

${ }_{43}$ SP, vol. II, pars III, 1006-1008: signum salutis elevatum"; ,in Ecclesia continuatur et ulterius actuatur quodammodo mysterium Christi Capitis (per incarnationem) totius humanitatis et Centri totius universi".

50 Tamże, 1005: .,Addatur verbum de Ecclesia uti signum visibile et efficax, eschatologicum, huius unitatis et consecrationis mundi". 
dek zbawienia powinno się uznać, kiedy jako taki zostaje rozpoznany. Inaczej mówiąc, człowiek powinien być gotowy zawsze do aprobaty Kościoła, jeżeli dostrzeże w nim środek zbawienia.

Jednakże Kościół katolicki, jako środek zbawienia, nie jest konieczny w sensie absolutnej konieczności. Bóg bowiem w swojej łaskawości i mądrości bynajmniej nie chciał zobowiązywać ludzi do faktycznego (in re) przyjmowania takiej instytucji zbawienia, o której nigdy nie słyszeli. Kościół katolicki zresztą też tego nie wymaga. Od ludzi żąda się tylko szczerej gotowości, aby z chwilą rozpoznania Kościoła, przyjęli go i uznali za środek zbawienia. Ci natomiast, którzy Kościoła nie znają i za środek zbawienia nie uznają, pozostają oczywiście zawsze zobowiązani wstąpić do niego, ponieważ w Kościele i przez Kościół, jako normalne i doskonałe narzędzie zbawienia, ma miejsce realizacja chrześcijańskiej religii odkupienia i chwały ${ }^{51}$.

Zacytujmy jeszcze jeden głos bpa P. Hurleya dobrze syntetyzujący to, co w eklezjologii jest najważniejsze. Jego zdaniem, ,prawdziwa natura Kościoła nie da się określić z pominięciem misterium Chrystusa, będącym misterium życia, teandrycznym, paschalnym, pentekostalnym, eklezjalnym, eucharystycznym i eschatologicznym" 52.

Nie nazywając rzeczy po imieniu, przytoczone wypowiedzi stoją na gruncie sakramentalnej koncepcji Kościoła. W ich ujęciu, misterium Kościoła sprowadza się do tego, że jego społeczność ludzka, dzięki swoim żywotnym związkom z Chrystusem, podobnie jak sakramenty, zbawienie Boże, zespalające ludzi z Bogiem i między sobą jednością Ducha Świętego, nie tylko oznacza, lecz także czyni obecnym w świecie i dostępnym dla człowieka.

\section{Schemat mariologiczny}

Jak wiadomo, Moderatorzy Soboru wobec różnicy zdań, jaka się ujawniła podczas debaty nad Schematem Konstytucji dogmatycznej o Kościele w kwestii połączenia $z$ nią, lub też nie, w jeden dokument soborowy Schematu Konstytucji dogmatycznej o NMP Matce Boga i Matce ludzi, poddali całą sprawę decyzji auli ${ }^{53}$. W czasie drugiej sesji Soboru (24. 10. 1963) dwaj kardynałowie, członkowie Komisji doktrynalnej,

¿1 Tamże, 1015: „Ecclesia catholica, ut medium salutis, non est de necessitate salutis absoluta, hoc sensu quod Deus, in sua benevolentia et sapientia, hominibus iugum iniquum imponere noluit accipiendi in re institutum quoddam salutis de quo numquam audierunt, nec Ecclesia catholica hoc imponit".

52 Tamże, 1019-1020: „Aliis verbis, vera Ecclesiae natura delineari non potest extra Mysterium Christi: mysterium scilicet vitae, theandricum, paschale, pentecortale, ecclesiale, eucharisticum et eschatologicum".

53 Zob. Moderatoris monitum circa schema de B. M. Virgine. AS, vol. II: Periodus secunda, pars III: Congregationes generales L-LVIII, TPV 1972, 298-299. 
przedstawili ojcom soborowym obie wykluczające się opinie wraz z argumentacją: F. König - za włączeniem ${ }^{54}$, R. Santos - przeciw włączeniu 55. Głosowanie nad odpowiednim wnioskiem w tej sprawie odbyło się kilka dni później (29. 10. 1963). Nieznaczna większość, licząca zaledwie czterdzieści głosów, zdecydowała wtedy, że Schemat mariologiczny stał się jednym z rozdziałów Konstytucji dogmatycznej o Kościele ${ }^{56}$. Stąd sensownym wydaje się już teraz, na etapie przygotowań soborowych, rozpatrzenie od strony formalnej i merytorycznej wzajemnej relacji tych tekstów. W szczególności będzie nam chodzić o to, czy Schemat o NMP w pierwszych swoich wersjach, wtedy właśnie powstałych, zawierał także jakieś ważne elementy dla sakramentalności eklezjalnej.

a. Przygotowawcza Komisja teologiczna zdecydowała się na opracowanie odrębnego Schematu mariologicznego dla licznych i bardzo poważnych racji. Przede wszystkim domagało się tego wiele setek biskupów w swoich postulatach soborowych. Wśród nich dwustu pięćdziesięciu postulowało dogmatyzację pośrednictwa wszystkich łask przez NMP. Przy tym chodziło także o protestantów, aby jasno przedstawić im katolicką naukę o NMP, a zwłaszcza, że jej pośrednictwo nie stoi w sprzeczności z Pismem świętym i dogmatem wiary o Chrystusie, jedynym pośredniku pomiędzy Bogiem i ludźmi. - Ale były i racje ze względu na przygotowywaną Konstytucję o Kościele. Ta bowiem byłaby niepełna, gdyby pominięto NMP, zajmującą z woli Chrystusa własne i szczególne miejsce w jego Mistycznym Ciele. Dlatego w związku z Konstytucją eklezjologiczną czymś koniecznym okazało się także zdecydowane odrzucenie przez Sobór pewnych współczesnych błędów mariologicznych, z których najbardziej niebezpieczny był ten, który opowiadał się za peryferyjną pozycją Matki Bożej w Ciele Mistycznym Chrystusa, a tym samym w kulcie i pobożności wiernych. Komisja teologiczna sądziła nawet, że milczenie Soboru na temat NMP stałoby się powodem zgorszenia dla wielu i to nie tylko wśród katolików, lecz także u prawosławnych, mogących podejrzewać, że stało się tak, aby przypadkiem nie zrazić protestantów ${ }^{57}$.

54 Relatio Em.mi ac Rev.mi Domini Card. F. König. Tamże, 342-345.

55 Relatio Em.mi ac Rev.mi Domini Card. R. J. Santos. Tamże, 338-342.

56 Quaesitum suffragiis subiciendum., ,Placet Patribus ut Schema de Beata Maria Virgine, Matre Ecclesiae ita aptetur ut fiat caput VI Schematis de Ecclesia? N. B.: Qui dicet 〈Placet〉 vult Schema de Beata Maria Virgine, Matre Ecclesiae fieri ultimum caput Schematis de Ecclesia. Qui dicet 〈Non placet〉 vult Schema de Beata Virgine, Matre Ecclesiae tractari ut Schema per se stans". Tamże, 345. Exitus suffragationis circa quaesitum quoad schema de B. M. Virgine, Matre Ecclesiae.. ,Praesentes votantes - 2193; Dixerunt placet - 1114, non placet — 1074; placet iuxta modum, sed hoc suffragium non erat requisitum, igitur nullum - 2; suffragia nulla - 3. Tamże, 627.

57 Por. Relatio Em.mi P. D. Alfredi Card. Ottaviani Praesidis Commissionis Theologicae, SP, vol. II, pars IV, $772-773$ oraz tamże s. 751, gdzie czytamy: ,Ad Commissionem Antepraeparationam Concilio Vaticano II apparando centena ac centena pervenerunt vota (circa 600), quibus postulatur ut hoc in Oecumenico Concilio sermo fiat de Beatissima Virgine Maria (cf. Acta et Documenta Concilio Oecu- 
Zredagowany przez Komisję teologiczną Schemat o NMP Matce Boga i Matce ludzi (De Beata Maria Virgine Matre Dei et Matre hominum) zbierał w jedną całość bardziej istotne problemy mariologii katolickiej ${ }^{58}$. Bazując na Piśmie św., Ojcach Kościoła i nauczaniu papieży, przeciwstawiał się zarazem zdecydowanie zarówno tym, którzy w jakikolwiek sposób szkodzili czci NMP, jak i wszelkiej przesadzie teoretycznej lub praktycznej, zagrażającej jej właściwemu kultowi. Nauka o pośrednictwie łask NMP została szeroko uwzględniona ale bez propozycji definicji dogmatycznej. O nastawieniu ekumenicznym Schematu najlepiej świadczy fakt, iz pominięto $\mathrm{w}$ nim pewne papieskie sformułowania mariologiczne, które choć same w sobie jak najbardziej uzasadnione, mogłyby się okazać zbyt trudne w zrozumieniu dla odłączonych braci protestantów ${ }^{59}$.

Komisja centralna cały ten tekst przedyskutowała w czasie swojej siódmej sesji. Warto przy tym zwrócić uwagę, że miało to miejsce w ramach dyskusji nad Schematem o Kościele. Dyskusja była raczej spokojna. Tekst na ogół podobał się wszystkim, o czym najlepiej świadczy wynik głosowania. Ilość głosów ,tak" nie ustępowała głosom warunkowym. Przy tych ostatnich zresztą zastrzeżenia i poprawki dotyczyły z reguły rzeczy nieistotnych ${ }^{60}$. Jedyną bardziej kontrowersyjną sprawą okazało się ujęcie pośrednictwa łask NMP. Nie negując samej prawdy, niektórzy, w tym również kard. G. B. Montini, obecny Papież Paweł VI, byli przeciwko samemu tytułowi „Pośredniczki” (Mediatrix) ze względu

menico Vaticano II apparando, Series I, Appendix voluminis II, Pars I, 1961, pp. 131-142). Immo, haud desunt qui vellent ut Concilium sive specialem quemdam tractatum 〈de augustissima Christi Matre〉, sive 〈Encyclicam〉 edat (cf. Acta et Documenta..., Series I, Vol. II, Pars II, pp. 540-543; 549), hoc eo vel magis quia videtur <futurum Concilium de Ecclesia valde imperfecte acturum esse nisi de Beata Maria Virgine quoque agatur, praesertim in hisce temporibus, ubi maximus conflictus adest fideles inter et Satanam (cf. Acta et Documenta..., Series I, Vol. II, Pars V, p. 103). Et sane, doctrina de Dei hominumque Matre tali via ac ratione hisce ultimis decenniis et a Summis Pontificibus et ab Episcopis et a theologis evoluta, pertractata est, ut iure meritoque tum a catholicis tum ab acatholicis expectetur clarum verbum quid reapse Ecclesia Catholica qua talis, de munere, privilegiis et cultu mariali credit, tenet docetque. Id autem opportune fit in peculiari Const.: De Maria Matre Dei et Matre hominum" (Praenotanda, I).

58 Zob. tekst w: SP, vol. III, pars I, 205-231 (Zwraca tutaj uwagę umieszczenie tego tekstu bezpośrednio po Schemacie De Ecclesia) oraz SP, vol. II, pars IV, $746-772$.

59 Por. SP, vol. II, pars IV, 773 (Relatio Em.mi P. D. Alfredi Card. Ottaviani, Praesidis Commissionis Theologicae) i 751-752 (Praenotanda, II-IV). Wśród pominiętych sformulowań mariologicznych papieży znalazły się między innymi: "Corredemptrix humani generis" (S. Pius X, Pius XI); "Reparatrix totius orbis" (I eo XIII); "materna in Filium iura pro hominum salute abdicavit" (Benedictus XV, Pius XII), ,merito dici queat Ipsam cum Christo humanum genus redemisse" (Benedictus XV), itp.

60 Tamże, 773-784. Dyskusja i glosowanie nad Schematem mariologicznym odbyły się po analogicznym rozpatrzeniu rozdzialów IX i $\mathrm{X}$ a przed przystapieniem do debaty nad rozdzialem XI Schematu De Ecclesia wraz z równolegle proponowanymi do nich odpowiednimi Schematami przez Sekretariat dla jedności chrześcijan. 
na błędne skojarzenia i zarzuty, jakie mógłby spowodować ${ }^{61}$. W sumie, Schemat mariologiczny został w całej rozciągłości przyjęty przez Komisję centralną. Stąd też nowa jego wersja zatytułowana ,Schemat Konstytucji dogmatycznej o NMP Matce Boga i Matce ludzi" (Schema Constitutionis dogmaticae de Beata Maria Virgine Matre Dei et Matre hominum) opracowana przez kompetentne organy - Podkomisję Komisji centralnej w porozumieniu z Komisją teologiczną — nosi tylko ślady drobnych retuszy stylistycznych ${ }^{62}$.

b. Z powyższego wynika, że mimo wszystkich więzi NMP z Kościołem, o jakich mówiło się w okresie przygotowań Vaticanum II, nie został jeszcze wyraźnie postawiony wtedy problem scalenia Schematu mariologicznego w jeden dokument soborowy ze Schematem o Kościele. W każdym razie milczą o tym oficjalne teksty.

W kwestii miejsca, jakie NMP zajmuje w Kościele, mariologiczny Schemat mówi co następuje: ,Ta bowiem dziewicza Rodzicielka, która miłościwie współpracowała, aby wierni rodzili się w Kościele, jest nie tylko najdostojniejszym, lecz wprost jedynym w swoim rodzaju czlonkiem Kościoła, także prawdziwym wzorem, a nawet Matką jest nazywana" 63. Ważne dla naszego tematu, sakramentalności eklezjalnej, wydaje się być tutaj przede wszystkim stwierdzenie, że ów szczególny czlonek Kościoła, „dziewicza Rodzicielka” jest „wzorem” Kościoła. W przypisie objaśniającym słowo „wzór” są cytowani św. Ambroży: „Maria, dobrze zaślubiona, lecz dziewica, ponieważ jest typem Kościoła”, oraz św. Augustyn: „Kościół jest bardzo podobny do Marii”; „W jego samego typie Kościoła Maria dziewica przodowała" ${ }^{64}$. Cytaty powyższe uprawniają do

61 Tamże, 777-778: „Card. Montini: Placet iuxta modum: in voto scilicet Cardinalis Liénart; ex intimo enim corde gaudeo et vehementer gaudeo de peculiari honore Beatae Mariae Virgini et Matri reddendo ab Oecumenico Concilio. Sed mihi inopportuna, imo damnosa videretur propositio de novo titulo, nempe mediatricis, Mariae Sanctissimae tribuendo. Vocabulum istud, scilicet mediatoris, unice et exclusive Christo est tribuendum, iuxta illud Apostoli: 〈unus est mediator . Extensio huius tituli non videtur verae pietati favere; nedum cultui mariano afferat novum argumentum, impedimentum mihi videtur adducere, quia obligat ad explicationem non satis facilem de usu analogico eiusdem tituli qui Christo et Matri Eius daretur diversa prorsus ratione, et quia fratres separatos magis ab unione cum catholica Ecclesia deterret. Loquendum est potius, secundum ordinariam magisterii ecclesiastici rationem, de universali maternitate spirituali Mariae Sanctissimae ac de Eiusdem regalitate ac mirifica et benignissima intercessione. non vero de mediatione".

62 AS, vol. I, pars IV , 92-121. - Por. przypis 21. I tutaj zwraca uwagę lączny druk obu Schematów - mariologicznego z eklezjologicznym.

${ }_{63}$ AS, vol. I, pars IV, 92, 93. Por. także pierwotną wersję tego tekstu w: SP, vol. II, pars IV, 747 oraz tamże, vol. III, pars I, 205.

64 ,S. Ambrosius, In luc. II, 7: PL 15, 1555 (1635-1636), CSEL, 32/4, 45: Maria 〈bene desponsata, sed virgo quia est Ecclesiae typus〉; cf. S. Augustinus, Sermo 213, 7: PL 38, 1064: 〈Mariae simillima est〉 Ecclesia. [...]; S. Augustinus, Sermo 25, De verbis Ev. Matthaei XII, 41-50: PL 46, 938: (In ipsius typo [Ecclesiae] Maria virgo praecessit ; ...". Zob. AS, vol. I, pars IV, 100 [101] oraz SP, vol. II, pars IV, 753-754 i tamże, vol. III, pars I, 212. 
wniosku, że słowo ,wzór” i ,typ” Kościoła w odniesieniu do Marii oznaczają to samo. W tekstach tych mamy zatem stwierdzenie pewnej anaIogii, zachodzącej pomiędzy fizyczną osobą Marii, która nie znając męża (por. Łk 1, 34) urodziła Syna Bożego (por. Łk 1, 32) - stała się Matka, i to swoje macierzyństwo dalej kontynuuje w porządku duchowo-nadprzyrodzonym pozyskując wyznawców dla Chrystusa w Kościele, a upersonifikowanym Kościołem, który także w znaczeniu przenośnym jest rodzicielką, a więc matką, sprawiającą jako nieskalana ,Oblubienica Baranka" (por. Ap 19, 7; 21, 2-9; 22, 17) swoją działalnością poprzez dawanie ludziom Chrystusa w głoszonym Słowie Bożym i sakramentach, rodzenie się dzieci Bożych. Niemniej w tej funkcji rodzenia Matka Najświętsza zawsze przodowała i nadal spełnia ją w ekonomii zbawienia tak istotnie i w takich rozmiarach, że staje się ,wzorem", czy ,typem" Kościoła. Stąd czytamy także w Schemacie: „Maria, która miała udział w założeniu Mistycznego ciała Chrystusa i która wzięta do nieba oraz ustanowiona Królową przez Pana, obdarza wszystkich macierzyńskim uczuciem, otrzymała nad wszystkimi pewien prymat i dlatego poddana Chrystusowi znajduje się (...) w samym centrum Kościoła" 65.

Nadto, wydaje się, że pewne światło w zrozumienie Kościoła-Sakramentu, czyli instytucji pośredniczącej w zbawieniu, może również wnieść to, co w Schemacie mariologicznym zostało powiedziane o pośrednictwie lask NMP i jego nierozerwalnych związkach z Chrystusem. W wieczności już przeznaczona, aby być Matką Boga i ludzi, na ziemi z Bożej Cpatrzności, Niepokalana Dziewica wiernie towarzysząc Chrystusowi aż pod krzyż, zdobywała dla ludzi łaski i tych jest hojną szafarką. Obecnie wniebowzięta, Maria w dalszym ciągu, pałając macierzyńską miłością, nie przestaje wstawiać się za ludźmi u Boga i przed Chrystusem. Złączona bowiem pozostaje z Osobami Trójcy Świętej w jedyny, tylko sobie właściwy sposób, tak że żadne inne stworzenie pod tym względem nie może się z nią równać. Wstawiennictwo Marii całą swoją siłę i skuŁeczność czerpie właśnie z tych powiązań, a zwłaszcza z krwawej ofiary Jezusa. Dla tych racji pośrednictwo łask NMP bynajmniej nie przekreśla i nie zmniejsza innej prawdy wiary, że jedynym Pośrednikiem pomiędzy Bogiem i ludźmi jest tylko Chrystus (por. 1 Tm 2, 5). Owszem, Maria jest pośredniczką, ale w Chrystusie. Jej pośrednictwo zatem nie płynie z żadnej konieczności, bo opiera się wyłącznie na niczym nie skrępowanym upodobaniu Boga oraz obfitości zasług Jezusa. W pośrednictwie Chrystusa biorąc początek, zawsze bezwzględnie od niego zależy.

65 AS, vol. I, pars IV, 93, 94. Por. także ten sam tekst bez retuszy stylistycznych w: SP, vol. II, pars IV, $747-748$ oraz tamże, vol. III, pars I, 206. 
W konsekwencji pośrednictwo Marii nie pomniejsza peśrednictwa Chrystusa; raczej je honoruje i wywyższa ${ }^{66}$.

Otóż analogicznie do NMP powinno się rozumieć i pośrednictwo łask Bożych, jakie dokonuje się w Kościele i przez Kościół, które tenże Kościół ukazuje i realizuje jako sakrament zbawienia. Kościelne pośrednictwo zbawienia wyrasta bowiem także z Chrystusa, od Chrystusa bezwzględnie zależy i do Chrystusa w swoim ostatecznym spełnieniu zdąża.

Wreszcie, Schemat mariologiczny wzmiankuje wśród wielu jeden czyn NMP, przy okazji którego sam Kościół został anonimowo nazwany sakramentem. „Ponieważ zaś sakrament ludzkiego odkunienia nie miał się wcześniej dokonać, aż obiecany przez Chrystusa Duch Święty zstąpi w dniu Pięćdziesiątnicy, oglądamy Marię wraz z Apostołami trwająca w Wieczerniku na modlitwie $(\mathrm{Dz} 1,14)$, upraszającą również swoimi prośbami wylanie Ducha" ${ }^{67}$. Nazwanie Kościoła sakramentem wydaje się nie ulegać $w$ tym tekście wątpliwości, ponieważ zwrot „odkupienia ludzkiego sakrament" oznacza tutaj ten etap ekonomii zbawienia, którym właśnie jest Kościół ${ }^{68}$. W związku z tym, że Schemat o Matce Bożej, który go zawiera, stał się w czasie Soboru integralną częścią Konstutucji o Kościele, mielibyśmy zatem w jakiejś mierze również w obrębie dokumentu eklozjologicznego do czynienia z ukrytym lecz rzeczywistym nazwaniem Kościoła Sakramentem odkupienia dla ludzi.

co AS, vol. I, pars IV, 93-95 [94-96] (De titulis quibus consociatio Beatae Virginis Mariae cum Christo in oeconomia nostrae salutis exprimi solet). Por. także pierwotną wersję zreformowanego ustępu w: SP, vol. II, pars IV, 748-749 oraz tamże, vol. III, pars I, 206-207.

67 AS, vol. I, pars IV, 93, 94: „Quoniam vero humanae redemptionis sacramentum non ante perfectum erit, quam promissus a Christo Spiritus Sanctus, in die Pentecostes, advenerit, Mariam una cum Apostolis in oratione in Caenaculo contemplamur perseverantem (cf. Act. 1, 14), suis quoque precibus effusionem Spiritus implorantem", AS, vol. I, pars IV, 93 [94]. - W pierwotnej wersji końcówka tego tekstu brzmiała nieco inaczej: „Maria, cum Apostolis in oratione perseverans (Act. 1 , 14) suis quoque precibus effusionem Spiritus impetravit". Por. SP, vol. II, pars IV, 747 i tamże, vol. III, pars I, 206. - Ostatecznie tekst ten pozostał w Konstytucji dogmatycznej o Kościele, ale z dość znacznymi retuszami stylistycznymi (n. 59).

68 Wynika to nie tylko z samej treści tekstu, lecz także z cytatu, którego on jest parafrazą. W gre wchodzi tutaj: Leo XIII, Litt. Apost. Iucunda semper, 8 sept. 1894: Acta Leonis XIII, XIV, p. 308, gdzie jest powiedziane: „Quoniam vero humanae redemptionis sacramentum non ante perfectum erit quam promissus a Christo Spiritus Sanctus advenerit, ipsam idcirco in memori Caenaculo contemplamur, ubi simul cum Apostolis pro eisque postulans inenarrabili gemitu, eiusdem Paracliti amplitudinem maturat Ecclesiae, supremum Christi donum, thesaurum nullo tempore defecturum". Inny cytat, przytoczony na poparcie omawianego sformulowania Schematu mariologicznego, jeszcze bardziej wyraźnie stwierdza, że chodzi w nim o Kościół: Pius XII, Litt. Encycl. Mystici Corporis: AAS 35 (1943) p. 248; „Ipsa fuit, quae validissimis suis precibus impetravit, ut Divini Redemptoris Spiritus, iam in Cruce datus, recens ortae Ecclesiae prodigialibus muneribus Pentecostes die conferretur", Por. AS, vol. I, pars IV, 106107 oraz SP, vol. II, pars IV, 759 i tamże, vol. III, pars I, 217. 


\section{SAKRAMENTALNOSC EKLEZJALNA W UJECIU POZOSTAEYCH SCHEMATOW SOBOROWYCH}

Sobór Watykański II w swoich podstawowych założeniach zarówno miał być, jak też w rzeczywistości okazał się Soborem o orientacji przede wszystkim pastoralnej. Nic więc dziwnego, że problematyka Schematów przygotowanych pod obrady soborowe koncentrowała się także wokół zagadnień duszpasterskich, objętych wspólnym mianownikiem ,aggiornamento", czyli odpowiedniego przystosowania Kościoła do współczesnych warunków życia ${ }^{69}$. Na skutek tego kwestie ściśle teologiczne, z eklezjologicznymi włącznie, z reguły zostały potraktowane w Schematach drugoplanowo i funkcjonalnie, tzn. o tyle, o ile było to niezbędne dla planowanej odnowy kościelnej. Nie inaczej rzecz się miała i z problemem Kościoła-sakramentu. Dlatego, oprócz co dopiero omówionego projektu Konstytucji o Kościele i Schematu mariologicznego, w kwestii sakramentalności eklezjalnej na odrębną analizę zasługują tutaj jedynie Schemat liturgiczny oraz Dekret pastoralny o ekumenizmie katolickim. Oba te dokumenty, program reformy liturgicznej i dialog ekumeniczny oparły bowiem na teandryczno-sakramentalnej wizji Kościoła. W innych Schematach na ten temat można znaleźć jedynie drobne wzmianki czy aluzje. Z tego względu zbierzemy je i przedstawimy łącznie.

A. Przedziwny Sakrament jedności Kościoła w Schemacie o liturgii świętej

Wywody na temat stanowiska przygotowawczej Komisji liturgicznej odnośnie Kościoła jako sakramentu wypada także rozpoczać od poddania w wątpliwość i odrzucenia opinii L. Boffa, wydanej o „historii powstania sakramentalnego pojęcia Kościoła Konstytucji liturgicznej" 70. Swój pogląd o Kościele-sakramencie w projektach wstępnych tego dokumentu L. Boff oparł prawie wyłącznie na wersji opatrzonej datą 10. 8. $1961 \mathrm{r}$. Prawdę mówiąc, wszystko, co w tym względzie zostało powiedziane przez Autora, stanowi mozaikę cytatów tego właśnie tekstu. Tymczasem, z danych Relacji kard. A. Larraona, przewodniczącego liturgicznej Komisji przygotowawczej wynika, że wspomniany projekt był wprawdzie

69 Autentyczny sens ,aggiornamento" sprecyzował bliżej Papież Jan XXIII w przemówieniu wygłoszonym podczas otwarcia Vaticanum II. AS, vol. I, pars I, 167-168: „Hanc coniunctionem cum Christo eiusque Ecclesia Concilia Oecumenica. quotiescumque ea celebrari contingit, sollemni quodam modo praedicant et veritatis lucem quoquoversus emittunt, vitam singulorum hominum, domestici convictus, societatis in rectas semitas dirigunt, spirituales vires excitant atque stabiliunt, ad vera et sempiterna bona continenter animas erigunt".

70 Boff, Die Kirche als Sakrament im Horizont der Welterfahrung, 234-237 (Die Entstehungsgeschichte des sakramentalen Kirchenbegriffes der liturgischen Konstitution). 
już trzecim szkicem roboczym Konstytucji o Liturgii świętej, ale nie ostatecznym. Zaraz po opracowaniu Komisja liturgiczna rozesłała go wszystkim swoim członkom, którzy nadesłali ponad 1500 rozmaitych wniosków. Wtedy cały tekst został przez kierownictwo Komisji przeredagowany i znowu wysłany $\mathrm{w}$ listopadzie tegoż roku zainteresowanym stronom. Po otrzymaniu dalszych uwag, ponownie uległszy przeróbkom, został wreszcie poddany ostatecznemu rozpatrzeniu i aprobacie na plenarnym posiedzeniu Komisji liturgicznej (12-13. 1. 1962). Przyjęty wówczas jednomyślnie (unanimi suffragio) i to we wszystkich swoich częściach Schemat ten wyraża i przedstawia dojrzały owoc prac przygotowawczych całej Komisji liturgicznej ${ }^{71}$.

Dla tych właśnie racji tylko on może stanowić podstawę do orzekania o zdaniu tejże Komisji w jakiejś sprawie. W związku z tym, należy tutaj zauważyć, że cytaty przytoczone przez L. Boffa na sakramentalność eklezjalną w ujęciu Schematu Konstytucji liturgicznej soborowego okresu przygotowawczego, w ogóle w nim nie figurują. W ostatniach redakcjach tekstu całkowicie znikły, a w ich miejsce pojawiły się zupełnie inne sformułowania. Stąd też nie mogą być one uznane za reprezentatywne dla prac przygotowawczych Komisji liturgicznej.

a. Rzecz zrozumiała, że Schemat ten ${ }^{72}$, starając się bliżej określić i sformułować podstawy teologiczne i ogólne zasady odnowy liturgicznej po Soborze, nie mógł pominąc ustosunkowania się i do problemu samego Kościoła. Wiadomo bowiem, że liturgia, choć nie wyczerpuje całej rzeczywistości Kościoła, to jednak spełnia w jego życiu funkcje o istotnym znaczeniu ${ }^{73}$. W ujęciu zresztą tegoż Schematu liturgia jest nawet ,aktem witalnym Chrystusa i całego jego mistycznego Ciała, źródłem i szczytem życia duchowego i pastoralnego Kościoła" ${ }^{74}$, a ,w pelnym i aktywnym uczestnictwie całego świętego ludu Bożego w czynnościach liturgicznych, zwłaszcza w Eucharystii, ma miejsce szczególne objawienia się Kościoła" 75. I trzeba nam tutaj od razu stwierdzić, że w tej perspektywie ukazane przez Schemat o Liturgii świętej pojęcie Kościoła jest nawskroś sakramentalne i to zarówno jeżeli idzie o jego mianownictwo jak i wyjaśnienie złożone pod adresem jego natury i misji.

I tak, Schemat liturgiczny, jako jedyny wśród siedemdziesięciu sześciu projektów przyszłych dokumentów soborowych nazwał wprost Koś-

71 SP, vol. II, pars III, 47-48 (Relatio Em.mi P. D. Arcadii Card. Larraona, Praesidis Commissionis liturgicae). Relacja ta $\mathrm{w}$ znacznej mierze była wzięta $\mathrm{z}$ relacji H. Bugniniego, sekretarza Komisji liturgicznej, złożonej na jednym z jej posiedzeń. Por. tamże, 47, przypis 1.

${ }_{72}$ SP, vol. III, pars II, 7-68: Commissio de sacra liturgia.

73 SP, vol. II, pars III, 4'9 i 51 (Relatio Em.mi P. D. Arcadii Card. Larraona Praesidiis Commissionis liturgicae); por. SP, vol. II, pars II, 13.

${ }_{74} \mathrm{SP}$, vol. III, pars. II, 16.

75 Tamże, 24. 
ciół sakramentem. Uczynił to cytując modlitwę odmawianą w Wielka Sobotę po drugiej lekcji (przed reformą Wielkiego Tygodnia) o ,,całego Kościoła przedziwnym sakramencie" 76 i św. Cypriana piszącego, że Kościół ,jest sakramentem jedności, tzn. ludem świętym zjednoczonym i uporządkowanym pod biskupem" 77. Zwraca przy t,ym uwagę fakt, że zarówno treść tych cytatów jak i bliższy kontekst, w którym się znalazły, nie zawierają dostatecznych objaśnień, z których można by się czegoś więcej dowiedzieć na temat sakramentalności eklezjalnej. Dopowiedzenie cytatu św. Cypriana, wzięte zresztą także z jego pism, odnosi się bowiem przede wszystkim do słowa ,jedność" a nie ,sakrament". Pokazując nadto tylko hierarchiczny wymiar tej jedności, tym samym dość jednostronnie zawęża sens sakramentalności Kościoła. Niemniej, wyraźne wprowadzenie nazwy sakrament na Kościól jest tutaj bardzo wymowne i należy je ocenić jako duże ,nowatorstwo" w dodatnim znaczeniu tego słowa. Dowodzi bowiem, że w kwestii nomenklatury eklezjologicznej przygotowawcza Komisja liturgiczna sięgnęła, zgodnie ze współczesnymi osiągnięciami badań teologicznych, do najstarszej, skrypturystycznej i patrystycznej tradycji chrześcijańskiej ${ }^{78}$.

Jednakże Schemat o Liturgii świętej zawierał coś więcej, a mianowicie takie określenia Kościoła, które jednoznacznie opowiadały się za jego sakramentalną strukturą. W zamierzeniach Komisji liturgicznej miały one charakter zasadniczy dla tego dokumentu, ponieważ znalazły się we Wstępie (prooemium), a więc jako idea przewodnia i podstawowa perspektywa wzajemnych relacji pomiędzy Kościołem i liturgią. Czytamy tam, co następuje: „Liturgia, przez którą sprawuje się dzieło odkupienia, najbardziej przyczynia się do tego, by wierni żyli i innym objawiali tajemnicę Chrystusa i nieskażoną naturę prawdziwego Kościoła, któremu właściwe jest to, że jest równocześnie boski i ludzki, widzialny i niewidzialny, Kościołem działania i kontemplacji, obecnym na świecie, a jednak pielgrzymującym. I to $w$ ten sposób, że w nim to, co jest ludzkie, pozostaje skierowane ku temu, co boskie, i mu podporządkowane; to, co dotyczy działania - ku kontemplacji, to, co teraźniejsze - ku przyszłej ojczyźnie, której szukamy. Stąd liturgia, budując codziennie wewnętrznie Kościół w świętą świątynię w Panu ..., w przybytek Boga w Duchu Swiętym (Ef 2, 21-22), aż do miary wieku pełni Chrystusa, w przedziwny sposób zarazem umacnia jego siły do przepowiadania Chrystusa; a tym, którzy są na zewnątrz ukazuje go

76 Tamże, 11: „totius Ecclesiae mirabile sacramentum”.

77 Tamże, 23: "Ecclesiae, quae est unitatis sacramentum scilicet plebs sancta sub Episcopo adunata et ordinata”. Chodzi o: „De cath. eccl. unitate, 7” oraz „Ep. 66 , n. 8, 3"'.

${ }_{78}$ Boff, Die Kirche als Sakrament im Horizont der Welterfahrung, 84-103 (Die Kirche als Sacramentum-mysterium im NT (oraz) in der Vätertheologie). 
jako znak wzniesiony dla narodów, w którym rozproszone dzieci Boże zostałyby zgromadzone w jedno, aż stanie się jedna owczarnia i jeden pasterz" 79. Załączona Deklaracja (declaratio) do Wstępu, precyzując bliżej merytorycznie ten tekst, wskazywala zarazem na charakter ekumeniczny tak ujętej natury i misji Kościoła. Ponieważ zachodzi pilna potrzeba wydobycia na światło dzienne i podkreślenia roli liturgii w życiu Kościoła, w stosunkach z braćmi odłączonymi i w pracy misyjnej, dlatego — jej zdaniem — wśród znamion Kościoła, w tejże liturgii życiowym doświadczeniem lepiej przez wiernych zgłębianych i przez nią lepiej objawionych na zewnątrz, tutaj podaje się to, co ma najdonioślejsze znaczenie w kontaktach z odłączonymi braćmi, ,a mianowicie jego naturę teandryczną, czyli równocześnie ludzką i boską, na wzór swego Założyciela, którego jest Ciałem Mistycznym i kontynuacją oraz objawieniem się na ziemi. Albowiem niekiedy u chrześcijan odłączonych istnieje pojęcie Kościoła, w którym tak podkreśla się jego aspekt duchowy, niewidzialny i eschatologiczny, że całkiem zanika jego aspekt widzialny i hierarchiczny. Stąd zarzucają oni często katolikom — zwłaszcza dzisiaj jakoby w Kościele widzieli tylko aspekt zewnętrzny, jurydyczny, hierarchiczny, administracyjny. Tymczasem właściwą nauką o Kościele jest, że jak samo Słowo Boże Wcielone, którego jest Ciałem, jest on równocześnie ze swojej istoty ludzki i boski i to tak, że w nim to, co jest ludzkie, jest przyporządkowane i podległe temu, co jest boskie" ${ }^{80}$.

Tenże Kościół wyposażony w kapłaństwo swojej Głowy Chrystusa, celem kontynuowania jego boskiej misji na ziemi, ,został ustanowiony w sprawach odnoszących się do Boga" (Hbr 5, 1): dla Bożej czci i wstawiania się za ludźmi ${ }^{81}$. Z zadania tego wywiązuje się głównie poprzez

79 SP, vol. III, pars II, 9: „Liturgia enim, per quam opus Redemptionis exercetur, summe confert ut fideles vivant et aliis manifestent mysterium Christi et genuinam verae Ecclesiae naturam: cuius proprium est esse simul humanam et divinam, visibilem et invisibilem, Ecclesiam actionis et contemplationis, in mundo praesentem et tamen peregrinam; et ita quidem ut in ea quod humanum est ordinetur ad divinum eique subordinetur, quod visibile ad invisibile, quod actionis ad contemplationem, et quod praesens ad futuram civitatem quam inquirimus. Unde, dum Liturgia Ecclesiam cotidie interne aedificat in templum sanctum in Domino..., in habitaculum Dei in Spiritu (Eph. 2, 21-22), usque ad mensuram aetatis plenitudinis Christi, miro modo simul vires eius ad praedicandum Christum roborat, eamque is qui sunt extra ostendit uti signum levatum in natationibus, sub quo filii Dei dispersi congregentur in unum quousque unum ovile fiat et unus pastor".

80 Tamże, 10: „Nempe natura eius theandrica, seu humama simul et divina, Fundatoris sui instar, cuius est Corpus Mysticum et continuatio atque manifestatio in hac terra. Apud christianos enim separatos quandoque viget conceptus Ecclesiae in quo eius aspectus spiritualis, invisibilis et eschatologicus ita extollitur, ut eius aspectus visibilis et hierarchicus penitus evanescat. Unde illi, praesertim hodie, saepius exprobant catholicis quasi in Ecclesia solum aspectum externum, iuridicum, hierarchicum, administrativum videant. Genuina vero doctrina catholica de Ecclesia est eam, sicut ipsum Dei Verbum Incarnatum, cuius est Corpus, esse simul ex essentia sui humanam et divinam, et ita, ut in ea quod humanum est ordinetur et subiciatur ei quod est divinum".

81 Tamże, 47. 
sprawowanie liturgii. Czynności liturgiczne nie są zatem jakimś prywatnym działaniem, lecz obrzędami Kościoła. Należąc do całego Ciała Mistycznego Chrystusa nie tylko je objawiają, ale i sprawiają. Poszczególne zaś członki pozostają w zasięgu ich oddziaływania w zależności od stanu, do którego przynależą i osobistego zaangażowania w ich uczestnictwo ${ }^{82}$. Funkcję składania Bogu należnej czci i uświęcania ludzi w szczególny sposób spełniają sakramenty i sakramentalia ${ }^{83}$.

W konsekwencji tego wszystkiego, Schemat o liturgii akcentował charakter inkarnatoryjny, a tym samym i sakramentalny ekonomii zbawienia, w świetle którego Kościól jest czymśs więcej niż zbiorem pomocy zbawczych, bo sam aktualnie stanowi wielki znak zbawienia i miejsce, gdzie realizuje się wspólnota życia z Bogiem. Znaki widzialne, jakimi posługuje się liturgia dla wspomnienia, sprawiania i zapowiedzenia niewidzialnej rzeczywistości Bożej, będąc z ustanowienia czy to Chrystusa, czy też Kościoła, są jedynie elementami uprzywilejowanymi kościelnego życia ${ }^{84}$. Zbawienie ludzkie posiada zatem również swój doczesny wymiar, eklezjalny kształt, w którym człowiek i otaczająca go rzeczywistość uczestniczą na różne sposoby w pośredniczeniu łaski Chrystusa.

b. Schemat liturgiczny, podobnie jak i inne Schematy, został także poddany dyskusji i głosowaniu Komisji centralnej ${ }^{85}$. Wiadomo też, ile niezadowolenia wśród niektórych członków i konsultorów przygotowawczej Komisji liturgicznej wywołało wprowadzenie don postulowanych wtedy zmian, czemu dali wyraz i to w dodatku na auli soborowej, tak że kard. C. Confalonieri, przewodniczący Podkomisji do rewizji Schematów, czuł się w obowiązku złożyć na ten temat Ojcom oficjalne wyjaśnienie ze strony Komisji centralnej ${ }^{86}$. Bezstronne zapoznanie się z przebiegiem obrad Komisji centralnej w tym względzie pokazuje wszakże cala bezpodstawność tych negatywnych reakcji. Chociaż pod adresem interesującego nas tekstu padło stwierdzenie, że jest najlepszym z dotychczas przedłożonych Komisji centralnej ${ }^{87}$, to jednak wiele spraw było tam mocno dyskusyjnych, a nawet przedmiotem kontrowersji. Do$\rightarrow \infty$

82 Tamże, 23.

83 Tamże, 37.

64 Por. tamże, 21 oraz A. P., La Chiesa sacramento e i sacramenti della Chiesa (XVII Settimana Lit. Naz. Italiana, Pavia 29 ag. - 3 sett. 1966), w: ,Ephemerides liturgicae", 80 (1966) 418.

85 Zob. SP, vol. II, pars III, 26-144; 275-368; 460-492. Dyskusja i głosowanie nad Schematem De sacra liturgia miały miejsce w czasie piątej sesji podczas kilku posiedzeń plenarnych Komisji centralnej, które odbyły się w dniach od 26 marca do 3 kwietnia $1962 \mathrm{r}$. - Por. Processus verbales congregationum tej sesji. Tamże, $13-21$.

86 Por. przypis 9 oraz ujęcie tej kontrowersji przez Schmidta w: Die Konstitution über die heilige Liturgie, 72-77.

${ }^{87}$ SP, vol. II, pars III, 71 (Card. Döpfner). 
wodnie świadczy o tym stanowisko zajmowane wówczas przez bioracych udział w debacie, którzy głosując zgłaszali powszechnie jakieś zastrzeżenia lub propozycje poprawek. Wśród spraw, co do których panowala największa i wszędzie pojawiająca się rozbieżność, należy wymienié przede wszystkim zakres kompetencji konferencji biskupich w kwestiach liturgicznych oraz status języka łacińskiego w liturgii ${ }^{88}$.

Z naszego punktu widzenia należy odnotować tutaj fakt, że dyskusja Komisji centralnej koncentrowała się zasadniczo wokół problemów pastoralnych a nie teologicznych. Nigdzie również nie widać w niej wzmianek na temat sformułowań eklezjologicznych Schematu o Liturgii świętej ${ }^{89}$. Rzeczy powiedziane tam o naturze i misji Kościoła były dla Komisji centralnej do tego stopnia oczywiste, że nikomu nie przyszło na myśl, aby cokolwiek kwestionować czy udoskonalać w proponowanej doktrynie. Stąd w nowym, dość znacznie zmodyfikowanym Schemacie Konstytucji o Liturgii świętej wypowiedzi pierwszej jego wersji odnośnie sakramentalności eklezjalnej pozostały nienaruszone, nie tylko co do treści lecz również i w swym ujęciu stylistycznym ${ }^{90}$. W ten sposób wizja sakramentalna Kościoła legła u podstaw i trwale poczęła określać całe dzieło reformy liturgicznej II Soboru Watykańskiego.

B. Kościół - powszechną pomocą do zbawienia według Dekretu pastoralnego o ekumenizmie katolickim

Wiadomo, że eklezjologia stanowiła od bardzo dawna szczególny przedmiot sporu pomiędzy chrześcijanami. Okazało się to już przy wielkiej schizmie (1054), w której istota kontrowersji sprowadzała się do różnic interpretowanej przez prawosławnych i katolików pozycji następcy św. Piotra biskupa Rzymu w Kościele. Swój punkt szczytowy kontrowersje eklezjologiczne osięgnęły z pojawieniem się reformatorów XVI w., którzy zarzucajac katolikom całkowicie eksteriorystyczne traktowanie Kościoła, a więc uznawanie go za instytucję czysto ludzką z pominięciem dokonującej się w niej wymiany darów łaski Bożej, ze swej

\footnotetext{
88 Por. tamże, Suffragia Sodalium, 79-102; 129-144; 307-316; 357-368; 485$-492$.

89 Por. tamże, Animadversiones Sodalium, 64-79; 116-129; 291-306; 336-357; $477-484$.

${ }_{90}$ AS, vol. I, pars I, 262-303; Schema Constitutionis de sacra liturgia. (= Schema constitutionis de sacra liturgia a secretario generali ad Patres missum est die 23 iulii 1962. Cf. Sacrosanctum Oecumenicum Concilium Vaticanum Secundum. Schemata Constitutionum et Decretorum de quibus disceptabitur in Concilii sessionibus. Series prima, TPV 1962, 157-200. ... In voluminis initio legitur: 〈SS.mus Dominus Noster Joannes Pp. XXIII, in audientia hac die infrascripto impertita, statuere dignatus est ut haec Constitutionum et Decretorum schemata, in Concili Oecumenico Vaticano secundo discutienda ad eiusdem Concilii Patres transmittantur. Ex Aedibus Vaticanis, die XIII mensis iulii anno MCMLXII. H. I. card. Cicognani, a publicis Ecclesiae negotiis $\rangle$ ).
} 
strony opowiadali się za Kościołem ukrytym i niewidocznym, realizującym się jedynie poprzez życie wiary, nadziei i miłości w wymiarach wewnętrznych duszy ludzkiej ${ }^{91}$. W tej sytuacji staje się jasne, że problemy eklezjologiczne należąc do zasadniczych w dialogu ekumenicznym, musiały się także zjawić i w Dekrecie pastoralnym o ekumenizmie katolickim 92. Rozwiązanie ich leży bowiem u podstaw postulowanego zrozumienia i pojednania chrześcijan.

a. Dekret o ekumenizmie stwierdzał, że ,jeden jest lud Boży, jeden Kościół Chrystusa, który ustanowiony przez Pana i ożywiany ustawicznie przez Ducha Świętego, trwa niezachwianie poprzez wieki w łasce Bożej, jaśniejąc jako znak wzniesiony wobec narodów (Iz 11, 12) miłości i jedności... Ugruntowany tak w organicznej jedności, na którą składają się elementy zarówno widzialne jak i niewidzialne, połączone ze sobą w sposób witalny, lud Boży pielgrzymuje w nadziei do mety najwyższej chwały" 93. Charakterystyczne i cenne dla naszego tematu: Kościoła-sakramentu, są także objaśnienia dane w przypisach do tego tekstu. Stanowią je cytaty $z$ dwóch najważniejszych pod tym względem encyklik papieskich: Satis cognitum Leona XIII (1896) i Mystici corporis Christi Piusa XII (1943). Według pierwszej, Satis cognitum, wyłącznie naturalistyczna czy mistycyzująca interpretacja rzeczywistości eklezjalnej jest nie do przyjęcia. ,Powiązanie i złączenie tych dwóch jakby czẹści jest wprost konieczne dla prawdziwego Kościoła i to prawie tak, jak dla natury ludzkiej wewnętrzny związek duszy i ciała. Kościół bowiem nie jest czymś obumarłym, lecz ciałem Chrystusa, obdarzonym życiem nadprzyrodzonym. Jak Chrystus, głowa i wzór, nie jest cały, jeśli się w nim widzi jedynie naturę ludzką widzialną, co czynią Fotymianie i Nestorianie, bądź tylko naturę boską niewidzialną, co znowu czynia Monofizyci, lecz jest jeden z dwóch i w obu naturach zarówno widzialnej jak i niewidzialnej, tak i jego ciało mistyczne nie jest praw-

31 Por. Consilia et vota communia episcoporum Germaniae, w: Acta et Documenta Concilio oecumenico vaticano II apparando. Series I (Antepraeparatoria), vol. II: Consilia et vota episcoporum ac praelatorum, pars I: Europa (sub secreto), TPV 1960, 743-744. Między innymi czytamy tam, s. 744: ,Haec dilaceratio et separatio Mystici Corporis Christi ab ecclesia visibili, cuius structura hierarchica et sacramentatis negatur, est quasi cardo totius controversiae inter catholicos et protestantes de Ecclesia". - Podobnego zdania był także Katalicki Uniwersytet Waszyngtońs'. Ameryki. Tamże, vol. IV: Studia et vota universitatum et facultatum ecclesiasticarum et catholicarum, pars II: Universitates et facultates extra Urbem (sub secreto), TPV 1961, 619-621.

92 Por. SP, vol. III, pars II, 446-453: Secretariatus ad Christianorum unitatem forendam. III. De oecumenismo catholico (Decretum pastorale).

${ }_{93}$ Tamże, 446; „Unicus etenim est populus Dei, unica Christi Ecclesia, quae, a Domino instituta et a Spiritu Sancto iugiter vivificata, saeculorum decursu indefectibiliter Dei gratia permanet veluti caritatis unitatisque fulgens 〈signum levatum in nationes) (Is. 11, 12)... Ita in organica unitate constitutus, quae elementis visibilibus necnon invisibilibus vitali modo connexis constat, populus Dei peregrinatur in spe ad gloriae supernae metam. 
dziwym Kościołem jak tylko dla tego, że jego części dostrzegalne biorą siłę i życie z darów nadprzyrodzonych, skąd wykwita własna ich racja i natura" 94. Cytaty z Mystici Corporis Christi dają z kolei między innymi bliższe określenie wzajemnego odniesienia i funkcjonowania tych dwóch odrębnych a zarazem zjednoczonych ze sobą części składowych Kościoła. Pomimo ich rodzajowego zróżnicowania, niższości struktury socjalnej w porównaniu $\mathrm{z}$ darami łaski, obie są jednakowo potrzebne. „Mocą władzy tzw. jurysdykcyjnej, z jaką Boski Odkupiciel posłał Apostołów w świat... on sam za pośrednictwem Kościoła chrzci, naucza, rządzi, rozwiązuje, związuje, składa ofiarę. Natomiast wyższym obdarowaniem, całkiem wewnętrznym i wzniosłym, o którym wspomnieliśmy mówiąc o sposobie, w jaki głowa działa na członki swoje, Chrystus sam ożywia Kościół Boskim swym życiem, przenika całe Ciało jego Boska swą mocá, a poszczególne członki karmi i utrzymuje wedle miejsca, jakie w ciele zajmują, w podobny sposób, jak szczep winny zrośniętym z sobą latoroślom daje życie i urodzajność" 95 .

Analizowany Dekret o ekumenizmie katolickim stwierdza nadto, że pewne dobra czy elementy eklezjalne znajdują się również poza widzialnym obrębem Kościoła. Odnosi się to przede wszystkim do życia łaski, wewnętrznych darów Ducha Świętego, cnót wiary, nadziei i miłości. Ale zasada ta weryfikuje się również i w odniesieniu do niektórych składników zewnętrznej budowy kościelnej. Tam gdzie Najświętszy Sakrament sprawowany bywa przez ważnie wyświęconych kapłanów zachowana jest Eucharystia. Również odrodzenie chrzcielne ma miejsce, jeżeli chrzest zostaje udzielony wedle ustanowienia Chrystusa. Dalej, Słowo Boże stanowi autentyczne źródło życia duchowego oddzielonych chrześcijan. U prawosławnych życie sakramentalne posiada duże znaczenie, ponieważ czynności liturgiczne sprawują wyświęceni hierarchowie.

Wszystkie te czynności święte religii chrześcijańskiej, istniejące u braci odłączonych, bez wątpienia stanowią dla nich źródło i środek zbawienia $i$ to we właściwym, choć nie doskonałym znaczeniu tego słowa. Niedoskonale, ponieważ cała pełnia środków zbawienia znajduje się tylko w prawdziwym Kościele Jezusa Chrystusa, który sam jeden jest ,powszechną pomocą do zbawienia”. Prawdziwie jednakże, bo rzeczywiście mogą one rodzić życie łaski, otwierać wstęp do społeczności zbawienia i doprowadzać do chwały niebieskiego Jeruzalem. Stąd też oddzielone

94 Tamże, 450, przypis 2. - Por. Leonis XIII Epist. Encycl. Satis cognitum (29 iunii 1896), ASS 28 (1895/96) 710 .

${ }_{95}$ Tamże, 450, przypis 2. Por. Pii XII Litt. Encycl. Mystici Corporis (29 iunii 1943), AAS, 35 (1943) 218. - Tłumaczenie polskie z małą, ale konieczną treściowo poprawką autora, jest pióra ks. A. Żychlińskiego. Zob. Mystici Corporis Christi. Encyklika Ojca św. Piusa XII o Mistycznym Ciele Chrystusa, Kraków 1944, 43. 
chrześcijańskie społeczności bynajmniej nie pozostają całkiem pozbawione jakiegokolwiek znaczenia i doniosłości w misterium powszechnego zbawienia. Dzięki wymienionym wartościom religijnym społeczności te, ożywione Duchem Świętym, prowadzą do tej wspólnoty kościelnej, w której wyłącznie spotkać można wszystkie środki zbawienia i która, wedle ustanowienia tegoż Chrystusa jest jedyną jego oblubienicą, do katolickiego Kościoła ${ }^{96}$.

b. Prezentując Schemat Dekretu o ekumenizmie przed Komisją centralną kard. A. Bea oświadczył w swojej Relacji, że jest w nim mowa przede wszystkim o wewnętrznym życiu Kościoła, tzn. o ekumenizmie usytuowanym w głębokiej asymilacji i widocznej manifestacji dóbr duchowych, które składają się na pełnię misterium Zbawienia w Chrystusie, a więc o takim ekumenizmie, który zakłada nawrócenie serca ${ }^{97}$. Jak już wspominaliśmy, tekst ten był tam rozpatrzony łącznie z ostatnim XI rozdziałem mówiącym o ekumenizmie Schematu eklezjologicznego, który także rozpoczynał się od bardzo znamiennych słów: ,Skoro Kościół, jako instytucja zbawienia jedna i szczególna, został zbudowany przez Chrystusa w charakterze jedynego znaku wzniesionego wobec narodów, nic nigdy nie może naruszyć jego wewnętrznej jedności" 98 . Tutaj należy stwierdzić, że oba teksty zostały wtedy ocenione i przyjęte bardzo dobrze. Zwrócono tylko uwagę, że pierwszy, mimo swej nazwy „Dekret pastoralny”, był raczej dokumentem doktrynalnym, natomiast w drugim, choć stanowił część projektu Konstytucji dogmatycznej o Kościele, dominowały właśnie elementy pastoralne. Powszechnie też postulowano scalenie w zgodnej miłości obu tekstów w jeden ${ }^{99}$. Niestety, Komisja teologiczna pozostawiając do debaty soborowej w Schemacie Konstytucji dogmatycznej o Kościele tylko własną wersję problematyki ekumenicznej, tym samym nie uwzględniła powyższych postulatów ${ }^{100}$.

$\mathrm{Na}$ sakramentalną koncepcję Kościoła przedstawionych dokumentów wskazują użyte określenia: ,powszechna pomoc do zbawienia" (generale auxilium salutis) oraz ,jedna i szczególna instytucja zbawienia" (unum singulareque institutum salutis). Określenia te implikują coś więcej w Kościele, niż zwykłe ukazywanie zbawienia, ponieważ mówią o pomaganiu przy zbawieniu na podobieństwo instytucji świeckich, dyspo-

96 Tamże, 446-447 oraz $451-452$, przypisy $3-7$.

97 SP, vol. II, pars IV, 804 (Relatio Em.mi P. D. Augusti Card. Bea, Praesidis Secretariatus ad Christianorum unitatem fovendam).

9s Tamże, 792; „Cum Ecclesia ut unum singulareque salutis institutum a Christo fuerit aedificata tamquam unum et unicum signum levatum in nationes, nihil umquam potest eiusdem unitatem intrinsecus violare'. - Tekst ten powołuje się na "Instructio S. Officii Ecclesia Catholica, 20 dec. 1949: A.A.S., 42 (1950), p. 144". Tamże, 797 przypis 1.

99 Tamże, 806-812.

100 AS, vol. I, pars IV, 81-91 (Schema Constitutionis dogmaticae de Ecclesia: Caput XI. De oecumenismo). 
nujących odpowiednimi środkami dla realizacji sobie właściwych celów. - Oba teksty nazywają także Kościół ,znakiem”, podciągając pod to miano nie tyle apologetyczną, w znaczeniu Vaticanum I 101, co dogmatyczną treść. Kościół bowiem jest znakiem jedności i miłości wobec narodów, jak u Iz 11, 12 (por. tamże 2, 2-3), czyli jedności mającej początek na ziemi, a w czasach mesjańskich Chrystusa definitywnie się realizującej, zwłaszcza dzięki eschatologicznemu spełnieniu 102. Jedność ta, w swej najgłębszej istocie stanowiąc wewnętrzny, pozazjawiskowy wymiar Kościoła, jest nienaruszalna. - Wreszcie, głównie Dekret pastoralny, ukazał implikacje ekumeniczne sakramentalnie rozumianej koncepcji Kościoła. Funkcję zbawczą, w jego ujęciu, spełnia nie tylko pełna realizacja Kościoła Chrystusowego. Poszczególne elementy eklezjalne mogą się znaleźć i faktycznie się znajdują również poza widzialną jego strukturą. Nie oznacza to jednakże zerwania $z$ nim wewnętrzno-nadprzyrodzonej jedności, więzi łaski, jaka się przez nie dokonuje, i tym samym utraty wszelkiej przydatności zbawczej, a więc i pośrednictwa w zbawieniu. Choć niepełne i niedoskonałe bywa jednakże w oddzielonych społecznościach chrześcijańskich rzeczywiste i skuteczne. W konsekwencji i one realnie partycypują w ,charakterze sakramentalnym Kościoła”, tzn. i one w jakiejś mierze spełniają funkcję Kościoła - powszechnego sakramentu zbawienia.

\section{Zbawcze posłannictwo Kościoła jako wyraz sakramentalnej koncepcji Kościoła dalszych Schematów soborowych}

Zebrane tutaj w jedną, luźno powiązaną całość ślady sakramentalności eklezjalnej soborowych Schematów pokazują dowodnie, że struktura sakramentalna Kościoła jest tak zasadnicza i fundamentalna dla jego rzeczywistości, iż nawet wtedy, kiedy nie zamierza się o niej wyraźnie

101 DS 3013 (1794): Conc. (oecum. XX) Vaticanum I: Constituto dogmatica „Dei Filius" de fide catholica.

102 Por. SP, vol. III, pars II, 450 przypis 1 (notae), gdzie w formie objaśnienia mamy cytowaną Encyklikę Leona XIII, Satis cognitum. Analogiczną interpretację spotykamy także w Schemacie o apostolstwie świeckich: „Unde ipsa signum levatum inter nationes semper exstitit, atque indesinenter unitatem generis humani aequalemque hominum dignitatem ac inter nationes et homines cuiuscumque stirpis palam docuit ac strenue defendit". De apostolatu laicorum. Tamże, 342. - Temu poszerzeniu interpretacyjnemu sensu znaku Kościoła, określonemu przez Vaticanum I, Komisja teologiczna była raczej przeciwna, co wynika z objaśnienia Schematu o zachowaniu nieskażonym depozytu wiary, danego przy omawianiu wyższości (praestantia) znaku Kościola. „Explicatur in quo consistat primatus signi quod est Ecclesia. Nihil additur descriptioni signi Ecclesiae a Concilio Vaticano I datae, quia additio deberet rem perficere, sed nulli sententiae privatae magis quam alii etiam licitae favere. Hoc autem videtur difficile". De deposito fidei pure custodiendo. Tamże, 67 i 63 . Wykładnię Vaticanum I znaku Kościoła Komisja teologiczna wprowadziła także do opracowanej przez siebie nowej formuły wyznania wiary. SP, vol. III, pars I, 12. 
traktować pojawia się zawsze, w mniej lub więcej wyraźny sposób, ilekroć są poruszone kwestie związane $z$ realizacją dzieła zbawczego Chrystusa na ziemi. A stało się tak, ponieważ przygotowawcze Komisje soborowe, formułując program reformy Kościoła dla Vaticanum II musiały siłą rzeczy w opracowanych tekstach zaakcentować wiele elementów, stwierdzających posługę zbawczą Kościoła względem ludzkości. Stąd ich wizja Kościoła jest funkcjonalna. Pokazują bowiem nie tyle jego naturę, co misję, czyli co i jak ma czynić Kościół, aby wypełnić postawione sobie zadania zbawcze przez Chrystusa. I właśnie w tej ich optyce ,funkcjonalnej” a nie „esencjalnej” Kościoła, należy szukać tego co, one mówią na temat eklezjalnej sakramentalności.

a. Stało się zwyczajem na wszystkich Soborach powszechnych składanie wyznania wiary przez ojców. Kodeks Prawa Kanonicznego nakazuje je zresztą i w innych okolicznościach życia kościelnego ${ }^{103}$. Jak wiemy, dzieje Kościoła znają różne formuły wyznań wiary. W tym, czym różnią się one między sobą, wskazują z reguły ne specyficzne przyczyny, dla jakich powstały. Wymownie dowodzi tego choćby zwykłe porównanie trydenckiego wyznania wiary $\mathrm{z}$ przysięgą antymodernistyczną ${ }^{104}$. Otóż i dla ojców Vaticanum II Komisja teologiczna przygotowała do opracowania Schemat nowej formuły wyznania wiary ${ }^{105}$, w którego tekście znalazły odbicie nie tylko stare, lecz również i współczesne problemy, wobec których stanęło chrześcijańskie „Credo”. I choć formuła ta nie przeszła ${ }^{106}$, ponieważ ostatecznie pozostano przy trydenckim wyznaniu wiary ${ }^{107}$, to jednak stanowi bardzo charakterystyczny dokument. Prawdy wiary, które Komisji teologicznej wydały się być zagrożone czy aktualne, zostały w niej bliżej sprecyzowane i silniej zaakcentowane.

Jeżeli idzie o problematykę eklezjologiczną, punkt szósty nowej formuły wyznania wiary mówił o ,,jednym Kościele Jezusa Chrystusa, arce zbawienia" 108. W dalszym ciągu tekst czynił aluzję do Dz 20, 28, aby pojęcie Kościoła przedstawić w sposób zrównoważony, tzn. objąć nim

103 Por. CIC, can. 1406.

104 Por. DS 1862 (994) - 1870 (1000): Professio fidei Tridentina; 3537 (2 145) 3550 (2 147): Iusiurandum contra errores modernismi.

${ }_{105}$ SP, vol. III, pars I, 11-14: Formula nova professionis fidei.

106 Według zamierzenia Komisji teologicznej, swoje wyznanie wiary podczas Vaticanum II ojcowie soborowi mieli już składać według nowej formuły. Po przedyskutowaniu na Soborze i ostatecznym ustaleniu tekstu miała ona zastąpić zarówno trydenckie wyznanie wiary jak i przysięge antymodernistyczną. Por. SP, vol. II, pars I, 499-502 (Relatio Em. mi P. D. Alfredi Card. Ottaviani, Praesidis Commi-ssionis theologicae) oraz $502-523$ (disceptatio). Komisja centralna tekst Nowej Formuly wyznania wiary przedyskutowała 9 listopada $1961 \mathrm{r}$. podczas drugiego posiedzenia plenarnego na drugiej sesji.

107 Por. Sesio publica I qua Concilium Vaticanum secundum sollemniter inchoatur 11 octobris 1962. AS, vol. I, pars I, 156-158 (Primae sessionis inchoatio et fidei professio).

${ }_{108}$ SP, vol. III, pars I, 12: „Unicam Jesu Christi Ecclesiam, salutis arcam, fide admitto". 
nie tylko aspekt mistyczny lecz także i prawny rzeczywistości eklezjalnej ${ }^{109}$. Wreszcie punkt siódmy stwierdzał, że zbawienie jest osiągalne tylko przez chrzest, „bramę Kościoła’, przyjęty faktycznie czy też tylko pragnieniem ${ }^{110}$. Tym samym została pośrednio stwierdzona również konieczność Kościoła do zbawienia, i to w takim samym znaczeniu, co sakramentu chrztu, tzn. jako nieodzownego i skutecznego środka. Dużą nowością $\mathrm{W}$ porównaniu $\mathrm{z}$ istniejącymi już symbolami wiary było więc tutaj zarówno postawienie obok siebie jak i wzajemne powiązanie Kościoła i zbawienia. W to junctim chrześcijanie oczywiście zawsze wierzyli, ale $w$ symbolach wiary $\mathrm{z}$ reguły go nie umieszczano. Formułowały one tylko przeważnie wiarę w Kościół bez bliższego precyzowania relacji do zbawienia ludzkiego.

b. Wydaje się, że i w innych Schematach soborowych sakramentalne spojrzenie na Kościół dochodzi do giosu także najbardziej wtedy, kiedy dotykają one wzajemnych związków Kościoła ze zbawieniem. Okoliczność mówienia o tych związkach implikuje z natury rzeczy potrzebę odpowiednich wyjaśnień na temat obu wspomnianych rzeczywistości. Dlatego ważne tu jest zdać sobie sprawę, o jakim zbawieniu mówią badane teksty, mianowicie, że chodzi w nich wyłącznie o zbawienie w sensie nadprzyrodzonym i eschatologicznym, i że Kościół jest zarówno dokonaną już realizacją jak i realizatorem tak pojętego zbawienia.

Najpełniej dał temu wyraz Schemat o jedności Kościoła „,aby wszyscy byli jedno”, Komisji Kościołów wschodnich. „Stwórca i odnowiciel rodzaju ludzkiego - czytamy tam - jeden i prawdziwy Bóg, wybrał nas (w Chrystusie) przed założeniem świata, abyśmy byli święci i nieskalani przed jego obliczem w miłości (Ef 1, 4), tzn. we wspólnocie z Nim i między nami ludźmi, ponieważ Bóg jest miłością (1 J 4, 16), i takie mamy od Niego przykazanie, aby ten, kto miłuje Boga, miłował też i brata swego (1 J 4, 21). Przez grzech, który jest nienawiścia (J 15, 22-25) ludzie poróżnili się z Bogiem i między sobą... Przez śmierć i zmartwychwstanie Jezusa Chrystusa stało się nowe stworzenie (2 Kor 5,$17 ; 6 a$ 6, 15), gdzie już nie ma Greka ani Żyda, obrzezania ani nieobrzezania, barbarzyńcy, Scyty, niewolnika, wolnego, lecz wszystkim we wszystkich Chrystus (Kol 3, 11; por. 1 Kor 12, 13; 6a 3, 28). Przyoblekając się przez Chrzest w Chrystusa jako Nowego Człowieka (6a 3, 27; Ef 4, 24; Kol 3, 10), wierni powracają do jedności z Chrystusem i między sobą: wszyscy bowiem są jednym w Chrystusie Jezusie (6a 3, 28). Stają się ciałem Chrystusa i członkami z członka (1 Kor 12, 27)...

109 Tamże, 13: „Alluditur ad Act. 20, 28, ut per modum unius significetur aspectus mysticus et aspectus iurisdicus Ecclesiae".

110 Tamże, 12: „Nullam autem esse salutem nisi per Baptismum, Ecclesiae ostium, sive re sive voto susceptum". 
Tym Ciałem Chrystusa jest Kościól (Ef 1, 22-23; 5, 23. 29-30; Kol 1, 18, 24; por. 1 Kor 12, 27-28), społeczność wybranych, którzy jednocza. się w Chrystusie i od niego otrzymują zbawienie. Zbawienie zatem nie dokonało się jeszcze w pełni. Sam Chrystus siedzi po prawicy Boga (Mk 16, 19, etc.), pełen chwały wiecznej i spełnionej: Chrystus powstawszy z martwych już więcej nie umiera, śmierć nad Nim nie ma już władzy (Rz 6, 9). Natomiast Chrystusowi wierni są nadal poddani grzechowi i śmierci, ponieważ ten świat nie zakończył się jeszcze przez powtórne przyjście Chrystusa. Stąd i podwójny stan Kościoła" 111. Chociaż zatem Kościół z jednej strony już się spełnił w niebie jako „nowe Jeruzalem" (Ap 3, 12), ,które w górze jest wolne” (6a 4, 26), „Oblubienica Baranka" (Ap 21, 9 nn.), to jednakże z drugiej strony tkwiac w świecie pozostaje niedoskonały i powinien się rozbudowywać na ,świętą w Panu świątynię" (Ef 2, 21) i rosnąć jak ciało „do miary wielkości według Pełni Chrystusa" (Ef 4, 13). Urządzony według struktur społeczności ludzkiej i powiązany z doczesnym porządkiem rzeczy posługuje się tymi rzeczami doczesnymi do osiagnnięcia większej chwały Bożej i zbawienia wiecznego ludzi ${ }^{112}$,

Inny Schemat zatytułowany: „Szczególne kwestie duszpasterskie” a przẏgotowany przez Komisję biskupów i zarządzania diecezją także wiele uwagi poświęcił wzajemnym relacjom pomiędzy Kościołem i zbawieniem, $z$ tym, że akcent został nie tyle na opis samego zbawienia, co na aktywną rolę Kościola w jego przekazie. Autorzy oczywiście nie zapominaja, że odkupienie ludzi dokonało się na krzyżu: „Chrystus bowiem raz umarł za grzechy, sprawiedliwy za niesprawiedliwych" (P 3, 18); ,w Nim mamy odkupienie przez Jego krew - odpuszczenie wy. stępków, według bogactwa Jego łaski" (Ef 1,7) ${ }^{113}$, ale przede wszystkim

111 SP, vol. III, pars II, 225: De Ecclesiae unitate 〈ut unum sint〉. Schemat ten został przedyskutowany przez Komisję centralną na piątym i szóstym posiedzeniu plenarnym siódmej sesji, odbytej w dniach od 16 do 18 czerwca 1962 r. Por. SP, vol. II, pars IV, 436-467. Tekst, który wszedł pod obrady Soboru, nie wykazywał zmian z przytoczonym. Por. AS, vol. I, pars III, 528-545.

112 SP, vol. III, pars II, 225-226 oraz 212: De Ecclesiae praeceptis. Schemat ten został także opracowany przez przygotowawczą Komisję Kościołów wschodnich. Komisja centralna przedyskutowała go na siódmym posiedzeniu plenarnym czwartej sesji w dniu 27. 2. 1962. Por. SP, vol. II, pars II, 862-877. - Por. nadto określenie Kościoła bardzo zbliżone do zacytowanego w Schemacie Komisji o apostolstwie świeckich. SP, vol. II, pars II, 304 (De apostolatu laicorum). - Schemat De episcoporum coadiutoribus et auxiliaribus deque episcoporum cessatione a munere pastorali Komisji biskupów i rządów diecezja stwierdzał w tym względzie, że ,animarum salus lex semper in Ecclesia fuit eritque suprema". SP, vol. III, pars I, 296. Dyskusja nad tym Schematem w Komisji centralnej odbyła się na pierwszym posiedzeniu plenarnym podczas szóstej sesji, w dniu 3 maja 1962 r. SP, vol. II, pars III, 643675.

113 SP, vol. III, pars I, 302: Praecipuae de animarum cura quaestiones. Komisja centralna przedyskutowala ten Schemat na pierwszym i drugim posiedzeniu plenarnym swej szóstej sesji, w dniach od 3 do 4 maja 1962. Por. SP, vol. II, pars III, 676-790. Poprawiona wersja nazywała się: Schema Decreti de cura animarum. AS, vol. II, pars IV: Congregationes generales L-LVIII, TPV 1972, 751-826. 
mówią o tym, że odkupieni ludzie ,przybrane synostwo" (6a 4, 5) sami nie są w stanie osiągnąc indywidualnym czy nawet zbiorowym wysiłkiem, mogą je natomiast otrzymać jedynie przez Kościół, będący ,filarem i podporą prawdy" (1 Tm 3, 15), ,który (Chrystus) nabył własną krwią" (Dz 20, 28) ${ }^{114}$. Przekaz, czy też aplikacja zbawienia nie została bowiem powierzona poszczególnym odkupionym ludziom, lecz Apostołom, których Chrystus posłał na cały świat, jak sam został posłany przez Ojca (I 20, 21). Zwyczajną ekonomię zbawienia złożył więc Chrystus w Kościele, co orzekł już I Sobór Watykański, stwierdzając, że „Pasterz odwieczny i biskup dusz naszych (1 P 2, 25), pragnąc uczynić trwałym zbawcze dzieło odkupienia, postanowił utworzyć święty Kościół, w którym jak w domu Boga żyjącego, wierni byliby złączeni więzami jednej wiary i miłości" 115. Ponieważ zbawienie, zarówno co do ludzi jak i w swej rozciągłości czasowej, jest powszechne, powszechnym i wiecznym jest Kościół. Wieczną i powszechną powinna być także działalność duszpasterska w Kościele ${ }^{116}$.

Niezmiernie ważnym jest przy tym stwierdzenie dalszych Schematów, że owo nadprzyrodzono-eschatologiczne zbawienie człowieka Kościół realizuje w oparciu o uczestnictwo w kapłaństwie Chrystusa, którym są naznaczeni, mimo istotnego zróżnicowania, wszyscy jego członkowie. „,Boski Odkupiciel - czytamy we wstępie do Schematu o formacji alumnów do służby Bożej — aby móc nieprzerwanie przedłużać aż do skończenia wieków trud odkupienia rodzaju ludzkiego, który sam spełnił wisząc na krzyżu, zechciał uczynić Kościół uczestnikiem swojego jedynego i wiecznego kapłaństwa; Apostołom bowiem i ich następcom w kapłaństwie przekazał władzę konsekrowania, ofiarowywania i posługiwania swoim własnym ciałem i krwią, a zarazem odpuszczania i zatrzymywania grzechów oraz ustanowił ich głosicielami Ewangelii i przywódcami nowego ludu wybranego" 117.

114 SP, vol. III, pars I, 303.

11. Tamże, 303-304: "Communicatio, enim, sive applicatio Redemptionis non unicuique hominum redemptorum relicta et commendata est, sed Apostolis quos Christus misit in universum mundum, sicut ipse missus fuerat a Patre. In Ecclesia tantum oeconomia salutis ordinaria a Christo posita est". Por. także DS 3050 (1821): Constitutio dogmatica I „Pastor aeternus” de Ecclesia Christi. Tłumaczenie tekstu podajemy za Breviarium fidei. Kodeks doktrynalnych wypowiedzi Kościota (opr. J. M. Szymusiak - S. Głowa), Poznań-Warszawa-Lublin 1964, 105. — Stwierdzenie kontynuacji dzieła zbawczego Chrystusa w Kościele znajdujemy w wielu Schematach. Przykładowo można zobaczyć jeszcze wstęp Schematu o szkołach katolickich. SP, vol. III, pars II, 140. Objaśniający go przypis 2 wyraźnie stwierdza: "In hac paragrapho imprimis statuitur principium continuitatis operis Christi in Ecclesia, et quidem ex divino mandato". Tamże, 149. - Zob. także poprawioną wersję tego Schematu po dyskusji Komisji centralnej odbytej $11-12$ czerwea podezas pierwszego i drugiego posiedzenia plenarnego siódmej sesji (SP, vol. II, pars IV, 110157). AS, vol. III, pars VIII: Congregationes generales CXXIII-CXXVII; Sessio pubiica V, TPV 1976, 953-972

116 SP, vol. III, fars I, 304.

117 SP, vol. III, pars II, 79: De sacrorum alumnis formandis. Schemat ten opra- 
Z kolei Schemat o apostolstwie świeckich stwierdzał, że kontynuacja dzieła apostolskiego Chrystusa na ziemi jest zadaniem całego Kościoła i że Kościół wykonuje je nie tylko przez hierarchię, lecz także przez pozostałych wiernych, którzy ,na skutek włączenia do Ciała Mistycznego i uczestnictwa w kapłaństwie Chrystusa, otrzymują przez Boga dane prawo i obowiązek na swój sposób wykonywać jeden apostolat Kościoła” 118. Kościół „bęđąc jedno z Chrystusem i kontynuując na ziemi królewskie kapłaństwo i dzieło Odkupienia, cały i bez przerwy oddaje się wypełnianiu Jego misji... A miłość Chrystusa, którą żyją Jego członkowie nikomu, kto pragnie być prawdziwym chrześcijaninem, nie poz-wala się uchylać od tego dzieła zbawczego. Kto bowiem Boga miłuje, nie może nie chcieć, aby wszyscy Go kochali; kto zaś prawdziwie miłuje swego bliźniego, jakby mógł nie pragnąć, czy nie chcieć jego wiecznego zbawienia...; jest to bowiem rzecz dobra i miła w oczach Zbawiciela naszego, Boga, który pragnie, by wszyscy ludzie zostali zbawieni i doszli do poznania prawdy" 119.

Cytowany nieco wcześniej Schemat o szczególnych kwestiach duszpasterskich, powołując się na Encyklikę Mediator Dei Papieża Piusa XII przypominał, że „Kościół ... sprawuje urząd kapłański przede wszystkim poprzez liturgię. Na pierwszym miejscu czyni to przy ołtarzu, gdzie się ofiara krzyża nieustannie przedstawia i odnawia, z różnicą jedynie w spo-

cowala przygotowawcza Komisja studiów i seminariów. Wstęp, pierwsze trzy rozdziały oraz rozdział piąty i szósty tego Schematu, przedyskutowała Komisja centralna na pierwszym posiedzeniu plenarnym siódmej sesji, 12 czerwca 1962. Por. SP, vol. II, pars IV, 24-110. Rozdział czwarty, w czasie szóstego posiedzenia plenarnego czwartej sesji, 26 lutego 1962 r. Por. SP, vol. II, pars II, 756-799. Poprawiona wersję tego Schematu zob. AS, vol. III: Periodus III, pars VII: Congregationes generales CXIX-CXXII, TPV 1975, 793-817. - Rolę sakramentów świętych w przekazie zbawienia Chrystusowego akcentował mocno Schemat o sakramentach i o świętej liturgii, opracowany przez Komisję dla misji: „Salvificum opus Christi, cunctis gentibus destinatum, parenne redditur assidua applicatione sacramentorum, quae 〈praecipua sanctificationis et salutis media〉 ex positiva voluntate divina instituta sunt". SP, vol. III, pars II, 272. Dyskusja Komisji centralnej nad tym Schematem odbyła się 30 marca 1962, podczas piątego posiedzenia plenarnego na piątej sesji. Por. SP, vol. II, pars III, 369-394.

${ }_{118}$ SP, vol. III, pars II, 309: De apostolatu laicorum. Tamże inny tekst powiada: „Opus apostolicum Christi in terris continuare totius Ecclesiae missio est, quam ipsa non solum per Hierarchiam exsequitur, sed etiam per caeteros christifideles. Ideo apostolatus, qui strictione sensu munus Apostolis concreditum dicit eorumque successoribus, latiore tamen sed vero sensu omnem Corporist Mystici actionem significat, qua regnum Christi in terris progreditur per applicationem fructus Redemptionis; et hoc sensu etiam laici de apostolatu Ecclesiae participant et cum Hierarchia, etsi diversimode, unum in Ecclesia apostolatum exercent".

119 SP, vol. III, pars II, 305. Na innym miejscu tenże Schemat wyraźnie stwierdza, że członkami Kościoła i uczestnikami kapłaństwa Chrystusowego wierni stają się przez chrzest i bierzmowanie: „Homo per sacramentum Baptismi i Corpus Christi Mysticum tamquam membrum inseritur atque per Confirmationem ad plenitudinem vitae christianae corroboratur. Iisdem sacramentis arcano sed reali modo participes redditur Regalis Sacerdotii Christi viribusque et donis spiritualibus abunde ditatur ut ex omnibus membris Christi genus electum, regale sacerdotium, gens sancta constituatur". Tamże, 307-308. 
sobie ofiarowania. Następnie czyni to przez Sakramenty, które są szczególnymi środkami udzielającymi ludziom życia nadprzyrodzonego. Wreszcie pełni swój urząd przez hymn pochwalny, który codziennie śpiewa Bogu Najwyższemu" ${ }^{200}$.

I trzeba tutaj jeszcze w końcu podkreślić, że owe związki Kościoła ze zbawieniem $\mathrm{w}$ oparciu o kapłaństwo Chrystusa, posiadane przez luả Boży, stanowią w ujęciu Schematów soborowych o istocie a zarazem i specyfice misterium Kościoła. ,Ze względu na swoją pewszechną i nadprzyrodzoną misję - wyjaśniał Schemat o wolności religijnej Sekretäriatu dla jedności chrześcijan - Kościół odznacza się znakomitą doskonałością, która przewyższa społeczności doczesne. Wyższego bowiem porządku spełnia prawa i obowiązki, których cywilna społeczność ani udzielić ani odebrać nie może, ponieważ zostały mu powierzone bezpośrednio przez boskiego Założyciela. Swoimi wyłącznie środkami nadprzyrodzonymi, mianowicie władzą hierarchiczną i znakami świętymi kultu ofiarniczego i sakramentalnego sprawia wspólnotę duchową Boga i ludzi, gdy wszystkim narodom aż do skończenia świata przekazuje dary miłości Bożej pochodzące od Ojca przez Syna w Duchu Świętym"121. Tę samą myśl w formie bardziej zwięzłej znajdujemy w ogólnym Wprowadzeniu Komisji o misjach do wszystkich przygotowanych przez nią Schematów, które stwierdza, że „Kościół... nie jest jakąś konstrukcją ludzką, lecz miastem Bożym, $z$ natury i celu naprzyrodzonym, czyli społecznością dzieci Bożych, która jednakże bywa zakładana i zamieszkiwana w granicach określanego narodu" 122 i miejsca. Jeszcze lapidarniej w tym względzie wyraził się Schemat o obrządkach w Kościele, nazywająe Kościół Jezusa Chrystusa „boską instytucją zbawienia”, odnoszącą się swoją naturą wprost do wszystkich ludów, wykluczywszy wszelką dyskryminację narodowościową czy rasową ${ }^{123}$.

Wszystkie przytoczone teksty ukazują misterium Kościola jako społeczność bosko-ludzką, w której zbawienie Chrystusowe nie tylko jest oznaczone, lecz także staje się obecnym. Samo zbawienie jest dobrem Boga, który zdecydował się obdarować swoją dobrocią ludzi i zarazen

120 SP, vol. III, pars I, 304-305. Por. AAS, 39 (1947) 522. Tłumaczenie pióra J. Wierusza Kowalskiego, w: Piusa XII encyklika Mediator Dei, z dn. 20 listopada 1947 r., Kielce 1948, 29.

121 SP, vol. III, pars II, 440: De libertate religiosa. Odnośnie dyskusji nad tym Schematem na Komisji centralnej por. przypis 40.

122 SP, vol. III, pars II, 242: Prooemium. Było to ogólne wprowadzenie do wszystkich siedmiu Schematów przygotowanych przez Komisję o misjach. Por tamże, 246-299. Wprowadzenie powyższe zostało przedyskutowane przez Komisję centralna łącznie ze Schematem De regimine Missionum, w czasie trzeciego posiedzenia plenarnego na piątej sesji, w dniach $27-28$ marca $1962 \mathrm{r}$. Por. SP, vol. II, pars III, $144-210$.

123 SP, vol. III, pars II, 189: De ritibus in Ecclesia. Schemat ten Komisja centralna przedyskutowała w czasie trzeciego i czwartego posiedzenia plenarnego na trzeciej sesji w dniach 17-18 stycznia 1962 r. SP, vol. II, pars II, 179-196. 
dobrem człowieka, który dzięki niemu staje się uczestnikiem życia Bożego. Dobro to jest zbawieniem, bo zrodziło się $\mathrm{z}$ niebezpieczeństwa: będąc utracone, zostało z powrotem odzyskane. Jest więc zbawienie darem miłości Bożej przez Chrystusa w Duchu Świętym, który grzeszną ludzkość pojednał z Ojcem i zarazem dobrowolnym uczestnictwem człowieka w tejże miłości, nawracającego się z grzechu i powracającego do Boga. Pod pewnym względem stanowi ono zatem wartość ahistoryczną, mianowicie wtedy, kiedy się je rozważa eschatologicznie, jako spełnienie i kres historii, czyli życie ludzi zbawionych lub potępionych kontynuowane poza czasem. Niemniej, to zbawienie eschatologiczne, juz w ziemskim życiu jest antycypowane, realizowane i obecne ${ }^{124}$. Chociaż na świecie nie widać jeszcze w pełni, kim będą ludzie oblekający się w Chrystusa, mocą Ducha Świętego są oni rzeczywiście dziećmi Bożymi. Czas obecny jest czasem Kościoła, ponieważ Bóg w Trójcy jedyny właśnie przez Kościół swoją wolę zbawczą objawia i urzeczywistnia względem ludzi. W tym sensie, tzn. jako widzialne objawienie i aktywna obecność zbawienia Bożego przez Chrystusa w Duchu Świętym, Kościół spełnia rolę powszechnego sakramentu zbawienia dla rodzaju ludzkiego.

c. O wizji sakramentalnej Kościoła w Schematach soborowych świadczy do pewnego stopnia również terminologia zastosowana do Kościoła, zwłaszcza nazwy: „Ciało mistyczne Chrystusa” i ,Matka - Kościół”. Określenia te bowiem w pewnej mierze implikują sobą realizację przez. naturę i misję Kościoła pojęcia i rzeczywistości sakramentów świętych.

Poza wyrazem Kościół, najczęściej spotykanym mianem tegoż Kościoła w Schematach soborowych jest miano Mistyczne Ciało Chrystusa. Wpływ Encykliki Mystici Corporis Papieża Piusa XII na tę częstotliwośc nie ulega najmniejszej wątpliwości ${ }^{125}$. Jeżeli idzie o nasz punkt widzenia - sakramentalność eklezjalną, o wiele ważniejszym pozostaje jednak uświadomienie sobie, że Autorzy poszczególnych Schematów, posỉugując się nazwą Mistyczne Ciało Chrystusa, wiązali z nią także ten sam sens, jaki nadała jej Piusowa Encyklika. Z wywodów zwłaszcza

124 Por. w tym względzie charakterystyczną wypowiedź Schematu o wolności religijnej. SP, vol. III, pars II, 436-437: „Ecclesia, licet ut regnum Christi non sit de hoc mundo ( $J 18,36)$, in mundo tamen est $(J 17,11)$ et ibi transcendit ordinem temporalem, quia missio eius universalis est et quia media, quibus illam exercet, ordinis supernaturalis sunt". - Por. nową wersję tego dokumentu w ramach Schematu o ekumenizmie. AS, vol. II, pars V: Congregationes generales LXV-LXXIII, TPV 1973, 433-441 (Caput V: De libertate religiosa).

12: W szczególności wchodzą tu w grę dwa passusy z tej Encykliki: ,Jam vero ad definiendam describendamque hanc veracem Christi Ecclesiam - quae sancta, catholica, apostolica, Romana Ecclesia est - nihil nobilius, nihil praestantius, nihil denique divinius invenitur sententia illa, qua eodem nuncupatur 〈Mysticum Jesu Christi Corpus〉". AAS, 35 (1945) 149; oraz: „Siquidem nihil gloriosius, nihil nobilius, nihil profecto honorificentius cogitari potest, quam sanctam, catholicam, apostolicam, Romanamque Ecclesiam participare, qua unius tam venerandi Corporis membra efficimur'. Tamże, 237. 
pierwszej części tej Encykliki wynika, że w skład rzeczywistości Mistycznego Ciała Chrystusa, czyli Kościoła, wchodzi zarówno jego aspekt zewnętrzny jak i wewnętrzny. Stąd „w ciężkim błędzie - twierdzi Encyklika - znajdują się ci, którzy według własnego upodobania tworzą sobie pojęcie o Kościele, jako o czymś ukrytym i całkiem niewidzialnym, a także ci, którzy go uważają po prostu za jakąś organizację ludzką, wzbogaconą pewną przymieszką dyscypliny oraz zewnętrznymi obrządkami, ale pozbawioną uczestnictwa w życiu nadprzyrodzonym" ${ }^{126}$. Misja Ducha Swiętego i władza jurysdykcji ,podobnie jak u nas ciało i dusza, wzajemnie się uzupełniają i doskonalą, i od jednego pochodza Zbawcy" 127.

Nie wchodząc bliżej ani w ocenę, czy też w szczegóły tej doktryny, tutaj chcielibyśmy tylko zauważyć, że również Schematy soborowe wią$\dot{z} a ̨$ z denominacją Mistyczne Ciało Chrystusa to samo znaczenie treściowe, tzn. używają jej dla przedstawienia całej, bosko-ludzkiej rzeczywistości Kościoła. Swiadczą o tym nade wszystko te ich zwroty, które mówią o „budowaniu” (aedificatio) Mistycznego Ciała Chrystusa. To budowanie czy wzrost dokonują się bowiem zarówno w ramach społeczności doczesnej jak i wspólnoty nadprzyrodzonej Kościoła. Co więcej, budowanie wymiaru wewnętrznego i zewnętrznego w Mistycznym Ciele Chrystusa nie dokonuje się w jakiejś izolacji od siebie. Jedno warunkuje drugie. „Kościół Chrystusa - czytamy w Schemacie o przykazaniach kościelnych - ... jako społeczność wybranych pozostająca na ziemi, powinien się rozbudowywać w świątynię świętą w Panu (Ef 2, 21), a jako ciało wzrastać do miary wielkości według pełni Chrystusa (Ef 4, 13)" ${ }^{128}$. W Mistycznym Ciele Chrystusa - stwierdza znany nam już Schemat o szczególnych kwestiach duszpasterskich — ,jesteśmy wszyscy członkami z członka i połączonymi naczyniami, poprzez które dokonuje się osmoza chrześcijańskiego życia duchowego" ${ }^{129}$. Wedle Schematu zajmującego się popieraniem powołań kościelnych, ,to budowanie Mistycznego Ciała, z woli samego Chrystusa, szczególniej zależy od posługi

126 Tamże, 223. Tłumaczenie polskie pióra ks. A. Żychlińskiego, w: Mystici Corporis Christi. Encyklika Ojca św. Piusa XII o Mistycznym Ciele Chrystusu, $51-52$.

127 Tamże, 224. Tłumaczenie polskie jak wyżej, 53. Stanowisko nasze w tym względzie pokrywa się ze zdaniem B. Kołodziejczyka, który na temat pierwszej części Encykliki Mystici Corporis pisze: „Papież uzasadnia w niej słuszność nazwy 〈mistyczne Ciało Chrystusa〉 w odniesieniu do prawdziwego Kościoła Chrystusowego, którym jest Kościół katolicki. W części tej występuje trzy razy sformułowanie, w którym Papież wyraża identyczność mistycznego Ciała Chrystusa z Kościołem". Por. tegoż Autora, Tożsamość Mistycznego Ciała Chrystusa $i$ Kościola katolickiego $w$ teologii katolickiej ostatniej doby (Studia dogmatyczno-moralne), Warszawa 1968, 25.

128 SP, vol. III, pars II, 212.

129 SP, vol. III, pars I, 337: Praecipuae de animarum cura quaestiones. 
kapłanów" 130. Ale także, co znowu oświadcza Schemat o apostolstwie świeckich, i „małżeńska społeczność ustanowiona dla rozmnażania rodzaju ludzkiego, będąc przez sakrament małżeństwa włączoną do Kościoła i żyjąc pełnością jego życia, z istoty swej jest nastawiona na budowe Ciała Chrystusa oraz wyposażona obficie do tego celu odpowiednimi łaskami" 131. Jeden z tekstów, opracowany przez Komisję o misjach, powiada nawet, że ,wszystkie narody mogą sobie świadczyć trud wzajemnej pomocy dla większego budowania całego Ciała Mistycznego Chrystusa, którym jest Kościół”, ponieważ miłość Chrystusa wznosi się ponad wszelkie różnice narodowe czy językowe. Miłość ta karmiąc się modlitwá objawia się właśnie przez świadczoną sobie pomoc ${ }^{132}$. Stąd, żeby jeszcze raz posłużyć się słowami Schematu o apostolstwie świeckich, ,jak misteria Wcielenia i Odkupienia ukazują miłość Bożą względem ludzi, tak samo wszystkie dzieła wiernych mają dzielić tę miłość z ludźmi w budowaniu Ciała Chrystusa a zarazem dawać o niej świadectwo" 133.

Celem różnorakiej działalności zbawczej Kościoła, wszystkich bez wyjątku jego członków, jest zatem ,,budowanie Mistycznego Ciała Chrystusa". Obdarowani przez otrzymane łaski Boże, chrześcijanie sami będąc częścią składową wznoszonej budowli, czynią to w podwójny sposób: udoskonalając już wierzacych i pozyskując niewiernych. Stąd i podwójny jest wzrost Ciała Mistycznego Chrystusa: jakościowy i ilościowy. Ale żaden nie występuje w odosobnieniu, niezależnie. Jeden wpływa na drugi, a nawet po części się z nim utożsamia. I właśnie to nierozdzielne, wzajemne warunkowanie się aspektu ziemskiego i nadprzyrodzonego w rozwoju i życiu Kościoła, wskazuje na jego sakramentalną strukturę, na to, że Ciało Kościoła jest zbudowane i żyje jak jego niedościgły wzór — Chrystus, Bóg i Człowiek zarazem.

Tytuł Matki jest drugim, obok miana „Mistyczne Ciało Chrystusa”, który najczęściej pojawia się w Schematach soborowych na określenie Kościoła. Kościół jest Matką, wyjaśnia jedna z not Schematu o szkołach katolickich, ,ponieważ udziela życia nadprzyrodzonego w obmyciu odrodzenia"134. Ta ,święta Matka Kościól - powiada także cytowany już pa-

130 SP, vol. III, pars II, 71: De vocationious ecclesiasticis fovendis. Schemat ten Komisja centralna przedyskutowała 24 lutego 1962 r., w czasie piątego posiedzenia plenarnego, na czwartej sesji. Por. SP, vol. II, pars II, 738-756.

131 SP, vol. III, pars II, 318.

13: Tamże, 245: Prooemium.

133 Tamże, 360 .

134 Tamże, 149 (3): ,Mater, quia vitam supernaturalem in lavacro regenerationis confert". - Tytuł ,Matki" na Kościól występuje niekiedy w towarzystwie innych, zwlaszcza "Nauczycielki" (Magistra), czy nawet ,Wychowawczyni" (Educatrix). Por. np. zwroty: ,In communitate Internationali Ecclesia ut Mater et Magistra gentium excellentiorem locum habere debet". SP, vol. III, pars I, 246 (Schemat: De Communitate gentium); "Ecclesia, gentium omnium mater et magistra”. $S P$, vol. III, pars II, 289 (Schemat: De studiis clericorum. Komisja centralna przedyskutowała ten Schemat 31 marca 1962 r. na szóstym posiedzeniu plenarnym 
rokrotnie Schemat o szczególnych kwestiach duszpasterskich - wstępując w ślady swojego boskiego Oblubieńca i Nauczyciela oraz posłuszna jego przykazaniom, bardzo troszczy się o to, aby wszyscy ludzie mieli życie i mieli je w obfitości $(J 10,10){ }^{135}$, a za swój najpoważniejszy obowiązek uważa troskę o królestwo Chrystusa na całej ziemi" ${ }^{136}$. Dla tych wlaśnie racji, jak to syntetycznie ujmuje Schemat na temat communicatio in sacris z niekatolickimi chrześcijanami wschodnimi, „Kościół Boży, który Chrystus Pan założyì całkowicie dla zbawienia wszystkich ludzi, wyposażony we wszystkie, konieczne do spełnienia tego zadania środki zbawienia, obdarza zawsze macierzyńską miłością nie tylko tych wiernych, którzy szczycą się mianem katolików, lecz i pozostałych ludzi, którym udziela w obfitości pomocy zbawczych, ponieważ ma zdać sprawę z ich dusz" ${ }^{137}$. Wreszcie, Schemat o stosunkach pomiędzy biskupami i zakonnikami, zwłaszcza w odniesieniu do podejmowanych dzieł apostolskich, poszerza zakres spraw objętych „macierzyńską miłością” Kościoła, kiedy stwierdza, że jednym $\mathrm{z}$ istotnych jego znamion jest katolickość (powszechność), co ma się rozumieć, nakłada nań ,matczyną troskę" o Wszystkie potrzeby świata. To „duchowe macierzyństwo” zostało Kościolowi powierzone przez Boga.

Rolę macierzyńską Kościoła przytoczone teksty rozumieją bardzo szeroko. Obejmując nią przede wszystkim sprawy związane bezpośrednio z nadprzyrodzonym zbawieniem ludzkim, nie wykluczają jej również z zakresu problemów doczesnych człowieka. Kościół jako Matka nie tylko rodzi życie Boże na świecie i obdarowuje nim ludzi, lecz także troszczy się o nie, pielęgnuje je i rozwija. Realizując tę swoją miłość macierzyŕska w zjednoczeniu $z$ Chrystusem względem całej ludzkości, w tym, i jako ,jedyna szafarka sakramentów" ${ }^{138}$, sam jest i ciągle staje się bardzo istotnie, powszechnym sakramentem zbawienia.

w czasie piatej sesji); ,Ecclesia Christi, Matrem, Magistram et Educatricem omnium popuiorum semetipsam agnoscens". Tamże, 140. - Por. także obszerne studium H. De Lubaca nt. macierzyństwa Kościoła (La maternité de l'Eglise), w: Les Eglises particulières dans l'Eglise universelle, Aubier 1971, 139-229. Swoje rozważania w tym względzie Autor rozpoczyna od zacytowania Scheebena: „La maternité de l'Eglise n'est pas une vaine appelation; c'est n'est pas une faible analogie de la maternité naturelle. Elle ne signifie pas seulement que l'Eglise se comporte envers nous comme une tendre mère... Cette maternité est aussi réelle que la présence du Christ est réelle dans l'Eucharistie, ou que la vie surnaturelle existe réellement dans les enfants de Dieu". Tamże, 141.

13, SP, vol. III, pars I, 333

136 SP, vol. III, pars II, 71: De vocationibus ecclesiasticis fovendis.

13: Tamże, 196: De Communicatione in sacris cum christianis orientalibus non catholicis. Schemat ten przygotowany przez Komisję dla Kościołów wschodnich, Komisja centralna przedyskutowała 19 stycznia 1962 r., w czasie piątego zebrania plenarnego na trzeciej sesji. Por. SP, vol. II, pars II, 229-247.

135 SP, vol. III, pars II 206: De Ecclesiae sacramentis „Sancta Mater Ecclesia, unica Sacramentorum dispensatrix". Schemat ten przygotowała także Komisja dla Kościołów wschodnich. Komisja centralna przedyskutowała go 19 stycznia 1962 r., w czasie piątego posiedzenia plenarnego, na trzeciej sesji. Por. SP, vol. II, pars II, $258-279$ 


\section{PODSUMOWUJACE WNIOSKI}

Swoje uwagi na temat eklezjologii Schematu Konstytucji dogmatycznej o Kościele L. Boff zakończył złośliwym, i chyba bez pokrycia w rzeczy, epitetem pod adresem teologii rzymskiej ${ }^{139}$. Patrząc na całość programu reformy Kościoła, a zwłaszcza na jego eklezjologię, tak jak się przedstawia w Schematach soborowych Komisji i Sekretariatów przygotowawczych Vaticanum II, trzeba rzeczywiście stwierdzić, że odbija on znacznie, może nie tyle swoim zakresem, co raczej swoją jakością opracowania, od dzieła Soboru. Niemniej musi się również lojalnie stwierdzić, że program ten stanowił wierny wykładnik tego, co myślał i czego wówczas chciał episkopat światowy łącznie z katolickimi uczelniami, i czemu dał wyraz w przeprowadzonym wstępnym sondażu opinii w okresie przedprzygotowawczym (1959-1960) ${ }^{140}$. Dzisiaj bowiem nie ulega watpliwości, że II Sobór Watykański był czymś więcej, niż wspólnym wykładnikiem idei i tendencji istniejących przedtem w Kościele. Rzeczywistość Vaticanum II stworzyła bowiem przez fakt swego zaistnienia ich nową wersję ${ }^{141}$. Autorytety, problemy i argumenty, które się wówczas pojawiły, uświadomiły ojcom soborowym wiele nowych spraw, o których wcześniej nie myśleli, oraz potrzebę ich uniwersalnego rozwiązania. Dlatego należy się wystrzegać, chcąc być w ocenie obiektywnym, osądzania etapu przygotowań soborowych według kryteriów powstałych w czasie Vaticanum II. Komisje przygotowawcze nie były Soborem i nim być nie mogły i nie chciały. Zrobiły to jedynie, co do nich należało. Rola ich sprowadzała się więcej do sugestii, niż do dania gotowych rozwiązań. Te miały przyjść z samym Soborem.

Studiując program reformy Kościoła, opracowany przez przygotowawcze Komisje soborowe, jest się pod dużym wrażeniem jego wszechstronności. Właściwie nie ma takiego odcinka życia kościelnego, którego by on nie uwzględnial. Oczywiście prymat wioda zagadnienia pastoralne, choć również i niektóre kwestie teologiczne nie mogły być i faktycznie nie zostały pominięte. W tym stanie rzeczy, eklezjologia niejako poprzez swoja nature, musiała się znaleźć w centrum tego programu. Bez odpowiednio wypracowanej koncepcji Kościoła zawisłby on po prostu w próżni. Mimo to, wydaje się, że na etapie przygotowań soborowych nie zdawano sobie jeszcze $z$ tego w pełni sprawy. Wprawdzie można spotkać

139 ,Zusammenfassend läst sich sagen: Was im Text vorgetragen wird, entspricht der 〈officiellen römischen Theologie〉 und lässt kaum die schon angebahnten Wege der modernen Ekklesiologie nach der Enzyklika 〈Mystici Corporis Christi〉 zu Wort kommen". Kirche als Sakrament im Horizont der Welterfahrung, 242.

${ }_{110}$ A. Kubiś, Kościót jako sakrament w soborowej dokumentacji przedprzygotowawczej, w: „Analecta Cracoviensia”, 8 (1976) 187-216.

141 Por. P. M. Gy, Situation historique de la Constitution, w: Vatican II. La liturgie apres Vatican II, (Unam Sanctam, 66), Paris 1967, 119. 
w tym względzie i opinie przeciwne, niemniej nie maja one pokrycia w tekstach. Są zwykłą projekcją sytuacji soborowej na okres przedsoborowy ${ }^{142}$. Opracowanie Schematu Konstytucji dogmatycznej o Kościele przez Komisję teologiczną, jak i dyskusja nad nim Komisji centralnej stanowiły tutaj tylko pierwszy krok. Pełne uświadomienie potrzeby samookreślenia się przez Kościół nastąpiło w czasie Soboru. Zarysowany program reformy domagał się bowiem czynnika koordynującego i scalającego. Kościół, chcąc się odnowić, stanął wtedy równocześnie pized koniecznością odpowiedzi na pytanie, za kogo sam siebie uważa i jaką istotną misję ma do spełnienia wobec świata.

O eklezjologii Schematów soborowych, a zwłaszcza projektu Konstytucji dogmatycznej o Kościele należy stwierdzić, że w zasadzie stała ona na gruncie doktryny o Kościele - Mistycznym Ciele Chrystusa. Z chwilą pojawienia się w Schemacie eklezjologicznym I Soboru Watykańskiego nauka ta stopniowo zaczęła sobie zdobywać coraz większe uznanie w teologii ${ }^{143}$. Zasadnicze jej elementy stały się również przedmiotem zwyczajnego nauczania papieskiego, głównie Leona XIII i Piusa XII w cytowanych już przez nas Encyklikach Satis cognitum ${ }^{144}$, Mystici Corporis Christi ${ }^{145}$ i Mediator Dei ${ }^{146}$. Mistyczne Ciało Chrystusa i Kościól, w okresie bezpośrednio poprzedzającym Vaticanum II, były używane zamiennie jako synonimy. Przyjęcie tej doktryny oznaczało definitywne przezwyciężenie hegemonii eklezjologii instytucjonalnej, która niepodzielnie panowała w świadomości katolików przez kilka wieków, od kontrreforma-

142 Przykładem takiej projekcji może być opinia L. Boffa, stwierdzająca, że 8. 11. 1960 r. Komisja centralna miała zdecydować, co następuje: .Das Leitmotiv und die Einheitsidee des ganzen Stoffes des Konzils die Idee der Kirche sein sollte". Die Kirche als Sakrament im Horizont der. Welterfahrung, 239. Nie potwierdza tego całość dokumentacji dotyczaca prac tejże Komisji.

143 Rzeczą, która w tym Schemacie uderza i stanowi nowość, jest pierwszy rozdział zatytułowany: „Kościół jest Mistycznym Ciałem Chrystusa” (Ecclesiam esse Corpus Christi mysticum). Schemat przygotowany pod dyskusję soborową zawierał zatem również niektóre elementy doktryny zapoznawane przez eklezjologię instytucjonalną. Więcej nawet! Pojęcie Mistycznego Ciała Chrystusa zostało w nin wysunięte na czoło, jako rodzaj definicji Kościola. W ten sposób jego struktura społeczna, widzialność, jedność, konieczność do zbawienia oraz inne przymioty dawniej podkreślane, zeszły niejako na dalszy plan. Bardzo charakterystyczną jest też argumentacja, jaką posłużono się uzasadniając to stanowisko, ponieważ uwzglẹdnia ona nie tylko racje pozytywne, a mianowicie, że określenie Mistyczne Ciảo Chrystusa zawiera wyraźną naukę Pisma św. i wyraża najgłębszą naturę Kościola, ale i racje polemiczne, tzn. miało ono zaprzeczyć obiekcjom protestantów, że katolicy całą naukę o Kościele sprowadzają do elementów zewnętrznych, jak i wyrazniej uświadomić ludziom, mało wrażliwym na wartości duchowe, jego zapomniany aspekt wewnętrzny. Według tejże argumentacji, niewiele zresztą można by powiedziec o postaci zewnętrznej Kościoła, jeśli się pominie jego stronę wewnętrzną. Por. Mansi, T. 51, 539 i 553 oraz A. Kubiś, Wprowadzenie do Lumen gentium Konstytucji dogmatycznej o Kościele, w: Idee przewodnie Konstytucji o Kościele, Kraków 1971, 15-16; 19-21.

1:4 DS 3300-3310 (1954-1962): Ep. encykl. Satis cognitum, 29 Iun. 1896.

145 DS 3800-3822 (2286-2291): Litt. encykl. Mystici corporis, 29 Iun. 1943.

146 DS 3840-3855 (2297-2297): Litt. encycl. Mediator Dei, 20. Nov. 1947. 
cji począwszy. W nowym ujęciu Kościół był już nie tylko „doskonałą społecznością", lecz także „,wspólnotą nadprzyrodzoną”, a więc czymś ludzkim i boskim zarazem. Pokazywało ono, że swoją naturą i misją do pewnego stopnia przypomina i kontynuuje samego Chrystusa ${ }^{147}$. Nie zamykając oczu przed różnorodnymi niedoskonałościami opracowania i przedstawiania tej nauki $\mathrm{w}$ Schematach soborowych, należy także lojalnie stwierdzić, że starały się one możliwie szeroko uwzględnić i zintegrować w dziele reformy wszystkie pozytywne osiągnięcia i zalety nauki o Kościele Mistycznym Ciele Chrystusa. Może najbardziej słabą ich stroną było tutaj niewystarczające uwzględnienie tych orientacji eklezjologicznych, które ze szczególną siłą zjawiły się po drugiej wojnie światowej, zwłaszcza biblijnej idei ludu Bożego ${ }^{148}$.

Jeżeli idzie o sakramentalność eklezjalną, w świetle której przestudiowaliśmy całą dokumentację Serii przygotowawczej Vaticanum II, to wnioski będą zróżnicowane, w zależności od tego, do jakich tekstów się odnoszą.

I tak, zarówno pierwsze dwie wersje Konstytucji o Kościele jak i dotycząca jej dyskusja Komisji centralnej, nigdzie nie nazywają wyraźnie Kościoła sakramentem. Nigdzie także nie ma śladów, aby ktoś postulował tego rodzaju mianownictwo. Zwrot Schematu mariologicznego ,sakrament ludzkiego odkupienia", niewątpliwie odnoszący się do Kościoła, na etapie przygotowań soborowych nie stanowił jeszcze integralnej części Schematu Konstytucji o Kościele.

Stwierdzenie powyższe nie oznacza oczywiście, że sama rzecz - eklezjalna sakramentalność - w ogóle nie występowała w Schemacie Konstytucji o Kościele. Wizja Kościoła naszkicowana w I rozdziale tego Schematu była istotnie sakramentalna, ponieważ stała na gruncie teandryzmu eklezjalnego.

Niewątpliwie pozostaje tutaj zagadką wstrzymanie się Komisji teologicznej od nazwy sakrament. Ale wydaje się, że nawet bez analizy samych akt jej prac, można pokusić się, przynajmniej częściowo, o wyświetlenie tej niewiadomej. Decydującą rolę w tym względzie odegrało z całą pewnością niewystępowanie miana sakrament na Kościół w nauczaniu Magisterium papieży. Nie dawała do tego zresztą wielkich podstaw również soborowa dokumentacja przedprzygotowawcza, gdzie określenie to było zarezerwowane przede wszystkim dla siedmiu sakra-

$1: 7$ Por. U. Valeske, Votum Ecclesiae, I. Teil: Das Ringen um die Kirche in der neueren römisch-katholischen Theologie. Dargestellt auf dem Hintergrund der evangelischen und ökumenischen Parallel-Entwicklung, München 1962, 196-216 (12 Kapitel: „Corpus Christi mysticum”); 217-236 (13 Kapitel: Die Encyklika ,Mystici Corporis" vom 29 Iuni 1943).

148 Tamże, 237-250 (14 Kapitel: Die ekklesiologische Entwicklung seit 1943). $\mathrm{Na}$ ss. 239-245 Autor pisze o „Die Hinwendung zum Begriff des 〈Volkes Gottes〉 als dem Ausgangspunkt der Ekklesiologie" i o ,Die Diskussion um das Verhältnis von 〈Volk Gottes〉 und 〈Leib Christi〉". 
mentów ${ }^{149}$. Wreszcie i z teologicznego punktu widzenia nie wszystkie elementy doktryny na tyle były wyświetlone, aby bez bliższych wyjaśnień mogły się znaleźć w dokumencie soborowym ${ }^{150}$.

Mimo to, naszym zdaniem, zaakcentowanie w Schemacie eklezjologicznym teandrycznego charakteru Kościoła, czyli jego analogiczności z misterium Słowa Wcielonego, posiadało istotne znaczenie dla późniejszego sformułowania sakramentalności eklezjalnej. Z chwilą bowiem powiedzenia tego, co stanowi kwintesencję problemu, zaistniały także odpowiednie przesłanki po temu, aby samą rzecz nazwać po imieniu. Dlatego można zaryzykować twierdzenie, że teandryczna koncepcja Kościoła, zaakcentowana przez Schemat o Kościele, nie pozostała bez wpływu w czasie obrad soborowych, zarówno na samo określenie Kościoła sakramentem, jak też i na wciągnięcie w jego orbitę oddziaływania innych, zasadniczych problemów eklezjologicznych.

Z kolei ujęcie sakramentalności eklezjalnej proponowane przez Sche.mat Konstytucji o Liturgii świętej i to, co na ten temat mówił co dopiero scharakteryzowany Schemat Konstytucji dogmatycznej o Kościele, wykazują zasadniczą tożsamość treściową. Oba dokumenty stoją bowiem jednakowo na gruncie teandryzmu eklezjologicznego, z tym, że Schemat liturgiczny jest bardziej zaawansowany, jeżeli idzie o zastosowaną terminologię. Słowa „sakrament”, czy „teandryczny”, jakimi on określa Kościół, nie widnieją — jak widzieliśmy - w Schemacie eklezjologicznym.

Tę ostrożność a zarazem i śmiałość terminologiczną można tutaj zrozumieć, gdy się zważy rangę doktrynalną obu dokumentów w kwestiach eklezjologicznych. W Konstytucji o Kościele mialy one stanowić same w sobie przedmiot uroczystego nauczania Magisterium soborowego, zaś w Konstytucji liturgicznej były przeznaczone raczej do spełnienia roli funkcjonalnej, tzn. miały pomóc we właściwym określeniu liturgii w życiu ludu Bożego. - Nadto wydaje się, że i sam skład personalny przygotowujących je Komisji, mianowicie teologicznej i liturgicznej, nie pozostawał tutaj także bez znaczenia. Zresztą Komisja teologiczna, odpowiedzialna za czystość doktryny, niejako z natury rzeczy musiała postẹpować z większą oględnością, niż inne Komisje przygotowawcze, w tym i liturgiczna.

Dla nas wszakże jedno jest ważne. Komisja centralna, która w swoich przedstawicielach stanowiła „mini-Sobór” i za taki przez wielu była uważana, w czasie dyskusji nad obu cytowanymi dokumentami nie podniosła nawet najmniejszych zastrzeżeń pod adresem tych ich sformułowań, któ-

149 Kubiś, Kościót jako sakrament $w$ dokumentacji przedprzygotowawczej II Soboru Watykańskiego, 206-212.

150 M. Bernards, Zur Lehre der Kirche als Sakrament. Beobachtungen aus de Theologie des 19 und 20 Jahrhunderts, w: Münchener theologische Zeitschrift", 20 (1969) 35-41 (Am Vorabend des Zweiten Vatikanischen Konzils). 
re wyraźnie, czy też tylko pośrednio, stały na gruncie sakramentalnej koncepcji Kościoła. Posiada to dlatego duże znaczenie, ponieważ świadczy o pełnej akceptacji tej nauki ze strony jej członków i konsultorów. W przeciwnym razie, powinny by się były zachować jakieś ślady, jeżeli już nie opozycji, to przynajmniej wątpliwości, i głosy sugerujące korekturę odnośnych tekstów. Tak więc zarysowana w swych podstawowych założeniach doktryna na temat sakramentalności Kościoła, przez Schematy: o Kościele i Liturgii, czekała do obrad Vaticanum II tylko na swoje całkowite „odkrycie" i głębszą penetrację w całokształt nauczania soborowego.

To, co pozostałe Schematy soborowe mówią w kwestii sakramentalności eklezjalnej, najlepiej ujmuje formuła Dekretu pastoralnego o ekumenizmie, nazywająca Kościół „powszechną czy ogólną pomocą do zbawienia". Kościól jest w nich z jednej strony owocem zbawienia, z drugiej zaś strony, całą swoją rzeczywistością stanowi środek służący do jego osiągnięcia. Do tej roli uzdolnił go sam Chrystus. Spełnia ją przez wszystkich swoich członków w oparciu o posiadane kapłaństwo Chrystusa. Daje im ono, na zróżnicowany sposób, bytową partycypację w godności mesjańskiej Chrystusa Proroka, Kapłana i Króla i zarazem czyni ich zdolnymi do realizacji Jego zbawczego posłannictwa wśród ludzi, celem zapewnienia im uczestnictwa we wspólnocie życia Bożego. Dzięki temu lud Boży, będący Kościołem, wyposażony w liczne środki zbawcze i możliwość działania zbawczego, sam również staje się w pewnej mierze znakiem i narzędziem tegoż zbawienia, czyli sakramentem.

Jest jednak rzeczą oczywistą, że we wszystkich omówionych tekstach sakramentalność eklezjalna występuje w bardzo zróżnicowany sposób i w mocno zróżnicowanym znaczeniu. Całą tę różnorodność form i treści można by objąć wspólnym mianownikiem ,śladów", a więc czymś, co wskazuje na „coś", świadczy o „czymś”, może naprowadzić do odkrycia „czegoś", a zarazem odzwierciedla do pewnego stopnia swój desygnat. Tym śladem, po którym można dotrzeć do sakramentalnej koncepcji Kościoła, odkryć ją niejako w strukturze i misji Kościoła, jeżeli idzie o miana Mistyczne Ciało Chrystusa i Matka Kościół, jest również głównie jego funkcja zbawcza względem ludzi na świecie. Oczywiście Schematy, zależnie od swego przeznaczenia i treści, ukazują różne jej warianty i możliwości realizacyjne. Jako Mistyczne Ciało Chrystusa Kościół jest w znacznym stopniu już zrealizowanym dziełem zbawienia, jako Matka z kolei, zajmuje się przede wszystkim jego realizacją. Posługując się powyższymi nazwami, tym samym Schematy soborowe stoją na gruncie, choć bez wyraźnego ujawnienia i sformułowania swych myśli, sakramentalnej koncepcji Kościoła. Innymi słowy koncepcję tę więcej domyślnie zakładają, niż świadomie się nią posługują i ją pokazują. 
W sumie powiemy, że problem Kościoła jako sakramentu nie został wyraźnie postawiony i sformułowany w przygotowawczej dokumentacji Vaticanum II. Zawiera ona tylko zasadnicze przesłanki po temu, łącznie z samą nazwą. Wszystko jednak, co na ten temat zostało tam powiedziane, nie pozwala jeszcze na bliższe określenie i sprecyzowanie poszczególnych jej elementów. Także rozmieszczenie tej nauki w Schematach jest różne. Najwięcej danych w tym względzie dostarczają Schematy Konstytucji o Kościele, Liturgii świętej oraz Dekret pastoralny o ekumenizmie katolickim. W tekstach innych Schematów, i to stosunkowo w niewielu, można mówić tylko o istnieniu mniej lub więcej widocznych śladów sakramentalności eklezjalnej.

\section{LA STRUCTURE SACRAMENTELLE DE L'ÉGLISE DANS LES SCHEMAS DES COMMISSIONS PRÉPARATOIRES DE VATICAN II}

\section{R E S U M E}

L'étude se propose d'étudier et de présenter le problème de l'Église au cours des travaux de préparation de Vatican II, c'est-à-dire en 1960-1962. En outre, il n'y s'agissait pas de toute l'ecclésiologie catholique, mais seulement de l'un de ses aspects, à savoir: dire si et en quelle mesure avait été traitée l'idée de la sacramentalité ecclésiale de l'Église conçue comme sacrement universel de salut. Pour répondre à cette question, nous prenons principalement appui sur ce qu'on appelle les Schémas conciliaires, c'est-à-dire les projets des documents, préparés par les Commissions et les Secrétariats compétents, pour être discutés et, éventuellement, approuvés par le Concile.

Ce même sujet - la sacramentalité ecclésiale - au cours du temps de préparation de Vatican II, n'a été traité, jusqu'à présent, que par L. Beff. Il faut toutefois constater, de suite, que la conception esquissée qu'il donne du problème est très fragmentaire. Il n'a trait qu'aux Schémas de la Constitution sur l'Église et la sainte Liturgie - et, ce qui est bien plus important, se base sur des texties partiellement non représentatifs à cette période-là. En outre, L. Beff ne tient pas du tout compte des travaux de la Commission centrale. Par suite, notre manière de concevoir la problématique de la conception sacramentelle de l'Église lors de la préparation du II-e Concile du Vatican, qui se base sur une documentation réellement représentative pour cette étape, est non seulement d'entièrement nouvelle, mais aussi la seule manière juste, du point de vue méthodologique, d'aborder le problème tout entier. Nos conclusions sont diversifiées selon les textes auxquels elles se rapportent.

Ainsi, ni les deux premières versions de la Constitution sur i'Église, ni la discussion à son sujet de la Commission centrale ne désignent eplicitement l'Église comme un Sacrement. On ne voit nulle part que qui que ce soit ait postulé une telle appellation. L'expression du Schéma mariologique, sacrement du salut de l'homme", qui se rapporte indubitablement à l'Église, ne constituait pas encore, 
au moment des préparations conciliaires, partie intégrale du Schéma de la Constitution sur l'Église.

L'affirmation ci-dessus ne signifie pas que la sacramentalité ecclésiale n'ait pas trouvé place dans le Schéma de la Constitution sur l'Église. La vision de l'Église, esquissée dans le chapitre I de ce Schéma, était en effet sacramentelle, car elle se basait sur le théandrisme ecclésial.

Reste certainement l'énigme de savoir pourquoi la Commission théologique ne s'est pas servie du mot ,,sacrement". Il semble cependant, que même sans analyser, de plus près, les actes de ses travaux, on peut tenter, tout au moins en partie, d'élucider cette inconnue. Un rôle décisif a été très certainement joué ici du fait que l'appellation de l'Église-Sacrement ne se trouvait pas dans l'enseignement du Magistère des papes. D'autre part, on ne la trouvait pas non plus suffisamment cians la documentation conciliaire antépréparatoire, où cette appellation était, avant tout, réservée aux sept sacrements. Enfin, tous les éléments de la doctrine n'avaient pas été tout-à-fait élucidés du point de vue théologique pour pouvoir être inclus, sans réserve, dans le document conciliaire.

Néanmois, à notre avis, le fait de souligner dans le Schéma ecclésiologique le caractère théandrique de l'Église, c'est-à-dire son analogie au mystère du Verbe Incarné, était d'une importance essentielle qui allait permettre de formuler plus tard la sacramentalité ecclésiale. Car, dès qu'on a dit ce qui constitue la quintessence du problème, les prémisses adéquates sont là également qui font appeler la chose par son nom. C'est pourquoi on peut se risquer à affirmer que la conception théandrique de l'Église, admise par le Schéma sur l'Église, n'a pas été sans exercer une influence au cours des débats du Concile, aussi bien pour désigner I'Église un Sacrement que pour attirer dans son orbite d'influence d'autres importants problèmes ecclésiologiques.

Ensuite, la conception de la sacramentalité ecclésiale proposée par le Schéma de la Constitution sur la sainte Liturgie et ce qu'à ce sujet disait le Schéma de la Constitution dogmatique sur l'Église - ce que nous venons de caractériser accusent une identité essentielle dans leur contenu. Les deux documents, en effet, prennent appui ici sur le théandrisme ecclésiologique, sauf que le Schéma liturgique est plus en avance s'il s'agit de la terminologie appliquée. Les mots „sacrement" et même „théandrique" par lesquels il désigne l'Église, n'apparaissent pas comme nous l'avons vu - dans le Schéma ecclésiologique.

On comprend cette prudence dans l'emploi de la terminologie si l'on tient compte du rang doctrinal des deux documents dans les questions ecclésiologiques. Dans la Constitution sur l'Église ces mots constituaient, par eux mêmes, l'objet de l'enseignement solennel du Magistère conciliaire, tandis que dans la Constitution liturgique. ils devaient plutôt avoir un rôle fonctionnel, c'est-à-dire aider à définir convenablement la liturgie dans la vie du Peuple de Dieu. Il semble de plus, que la qualité des personnes qui ont fait partie des Commissions, - la théologique et la liturgique -, n'est pas sans importance ici. Du reste, la Commission théologique, responsable de la pureté de la doctrine, se devait de procéder avec plus de circonspection que les autres Commissions de préparation, y compris la liturgique.

Une chose cependant demeure importante pour nous. La Commission centrale, qui par ses représentants constituait un ,mini-concile” et beaucoup la considéraient comme telle, n'a pas soulevé la moindre réserve, au cours des discussions concernant les deux documents, sur la manière dont ils étaient formulés et sur ce que, soit directement, soit indirectement, ils se basaient sur la conception sacra- 
mentelle de l'Église. Ceci est d'une grande importance, car cela témoigne que cet enseignement était pleinement accepté par ses membres et ses consulteurs. S'il en avait été autrement, on devrait retrouver des traces sinon d'opposition, du moins de doute, ainsi que des suggestions pour amender les textes en question. Ainsi donc, la doctrine de la sacramentalité de l'Église, ébauchée dans ses principes essentiels, par les Schémas sur l'Église et la Liturgie, n'a attendu les sessions de Vatican II que pour être ,découverte" et pénétrer plus profondément l'enseignement conciliaire.

Ce que les autres Schémas conciliaires disent au sujet de la sacramentalité ecclésiale est le mieux présenté dans la formule du Décret pastoral sur l'oecuménisme catholique et qui désigne l'Église comme ,l'aide universelle ou générale du salut". L'Église y est d'une part le fruit du salut, de l'autre elle constitue par sa réalité le moyen d'obtenir ce salut. Le Christ Lui-même l'a dotée pour ce rôle. Elle le remplit par tous ses membres en prenant appui sur le sacerdoce du Christ Ce sacerdoce leur permet de participer, de différentes manières, à la dignité messianique du Christ Prophète, Prêtre et Roi, et les rend aptes à réaliser sa mission salvatrice parmi les hommes afin d'assurer à ces derniers la participation à la vie de Dieu. Grâce à cela, le Peuple de Dieu, qui est l'Église, doté de nombreux moyens de salut et de possibilités d'action salvatrice devient aussi, en une certaine mesure, le signe et l'instrument de ce salut, autrement dit Sacrement.

Il est évident que, dans tous les textes traités cette sacramentalité ecclésiale apparaît aussi sous une forme très diverse et avec une signification également très diverse. On pourrait, quand même, réunir toute cette hétérogénéité de forme et de sens sous le commun dénominateur ,traces", donc quelque chose qui indique ,quelque chose", témoigne de „quelque chose", peut mener à découvrir ,quelque chose" et qui, en même temps, reflète à un certain degrè, son désignatif. Cette trace, suivant laquelle on peut arriver à la conception sacramentelle de l'Église, la découvrir, pour ainsi dire, dans la structure et la mission de l'Église, s'il s'agit des appellations Corps Mystique du Christ et notre Mère l'Église, les plus fréquentes dans les Schémas analisées, est de même constituée, par sa fonction salvatrice à l'égard des hommes sur terre. Il va de soi, que les Schémas, selon leur destination et leur contenu, montrent diverses variantes et possibilités de sa réalisation. En tant que Corps Mystique du Christ, I'Église est déjà en grande partie l'oeuvre réalisée de salut; en tant que Mère, elle s'occupe avant tout de sa réalisation. En se servant de ces appellations, les Schémas conciliaires se basent, bien que sans dévoiler ni formuler neettement leur pensée là-dessus, sur la conception sacramentelle de l'Église. En d'autres mots, ils établissent plutôt cette conception comme une conjecture qu'ils ne s'en servent ni la montrent consciemment.

En somme, nous dirons que le problème de l'Église en tant que Sacrement n’a été ni posé ni formulé nettement dans la documentation de la préparation de Vatican II. Elle n'en contient que les prémisses essentielles, conjointement avec l'appellation. Cependant, tout ce qui y a été dit à ce sujet ne permet pas encore de mieux définir ni de préciser ses divers étéments. De même, la répartition de cet enseignement est diverse dans les Schémas. On trouve le plus de données dans les Schémas de la Constitution sur l'Église, sur la sainte Liturgie ainsi que dans le Décret pastoral sur l'oecuménisme catholique. Quant aux autres Schémas, on ne peut dire de leurs textes, et ils sont en nombre relativement restreint, qu'jl s'y agit seulement de traces plus ou moins visibles de la sacramentalité ecclésiale. 